Document downloaded from:

http://hdl.handle.net/10251/98022

This paper must be cited as:

Gargallo Bellés, S.; Martín Monerris, M.; Oliver Rajadel, N.; Hernández Crespo, C. (2016). Sedimentation and resuspension modelling in free water surface constructed wetlands. Ecological Engineering. 98:318-329. doi:10.1016/j.ecoleng.2016.09.014

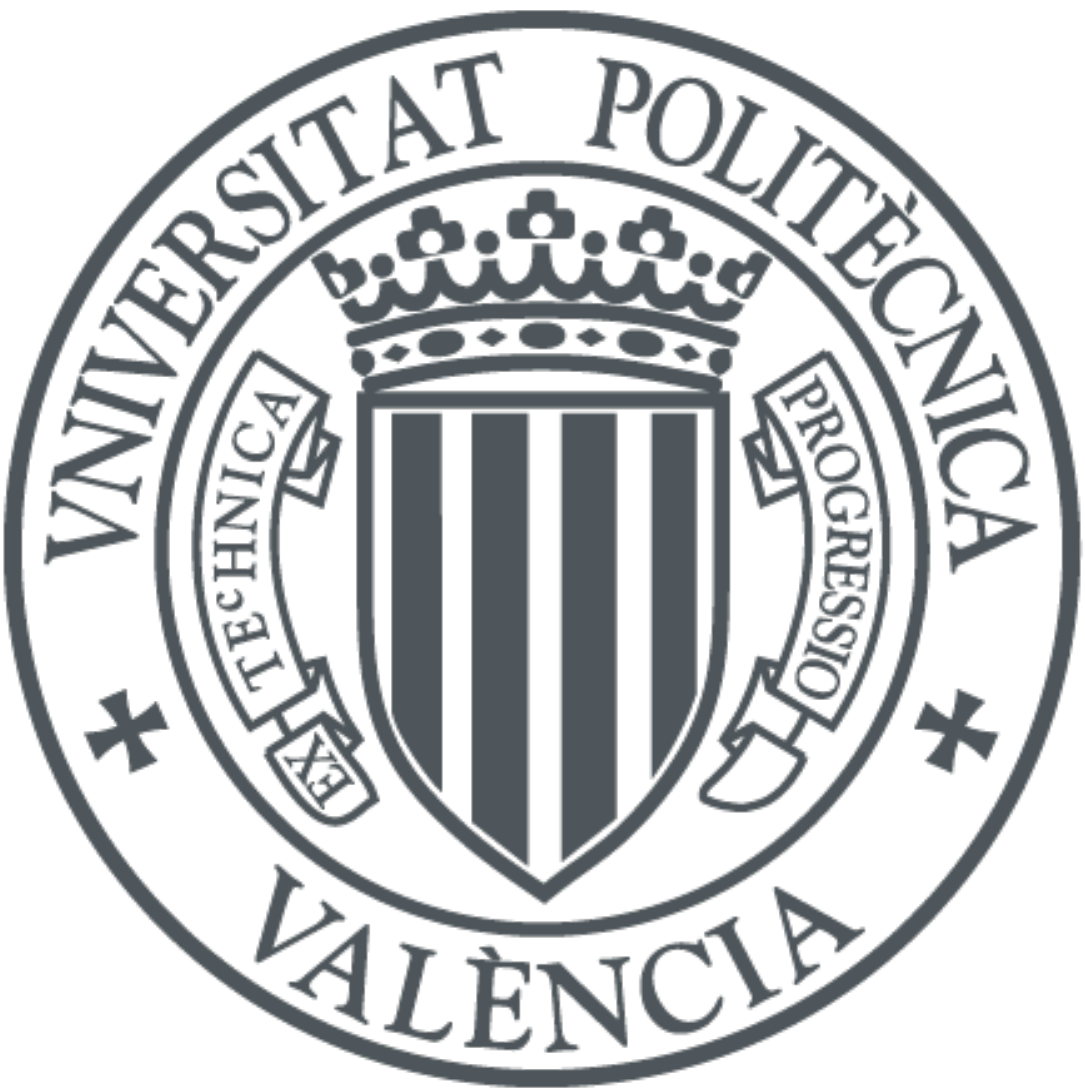

The final publication is available at

http://doi.org/10.1016/j.ecoleng.2016.09.014

Copyright Elsevier

Additional Information 
9 Abstract

3

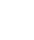

5

(

(

\title{
SEDIMENTATION AND RESUSPENSION MODELLING IN FREE WATER SURFACE
}

\section{CONSTRUCTED WETLANDS}

\author{
$\underline{\text { S. Gargallo }}^{1} *$, M. Martín ${ }^{1}$, N. Oliver ${ }^{1}$, C. Hernández-Crespo ${ }^{1}$ \\ ${ }^{1}$ Research Institute of Water and Environmental Engineering, \\ Universitat Politècnica de València, Cno. de Vera s/n, Valencia, Spain \\ sagarbel@upv.es
}

Eutrophication is a widespread problem that is being tackled from many perspectives and the recently applied technology of constructed wetlands is being used in the treatment of eutrophic water. However, process-based models to simulate their performance are scarce, so in this work a mechanistic model was developed to simulate the removal of total suspended solids, phytoplankton and total phosphorus in free water surface constructed wetlands treating eutrophic water. The model represents the influence of the main factors of the biotope and biota on these water quality variables, and particular attention is paid to resuspension produced by wind and by avifauna. Likewise, the effect of emergent vegetation cover in sedimentation, resuspension and phytoplankton growth is included. Phytoplankton is considered to store phosphorus internally in order to use it when growing, and the contribution of phytoplankton concentration to the suspended solids budget is included. The software AQUASIM was used to calibrate and validate the model in two full-scale constructed wetlands treating eutrophic water from Lake l'Albufera de València (Spain) for three years. The simulated data and field measurements showed satisfactory adjustments for the three studied variables. The budgets obtained for each variable reveal that sedimentation and resuspension are the main processes in total suspended solids performance. 
27 Sedimentation of organic particulate phosphorus is the most important process in total phosphorus removal. The sum of the effect of resuspension by avifauna and by wind increases by more than $50 \%$ the quantity of solids that enters the water column. The model reveals that simulating the effects of the emergent vegetation cover and resuspension is crucial for representing the performance of the studied variables.

Key words: suspended solids, phosphorus, phytoplankton, modelling, constructed wetland, avifauna.

\section{Introduction}

Loss of water quality in natural water bodies has become a major environmental problem for decades and many initiatives aimed at recovering good environmental status have been carried out. Eutrophication is one of the most globally widespread

40 problems and it is considered one of the main stressors on lakes (Ballatore and

41 Muhandiki, 2002). In eutrophic water bodies, turbidity is a critical parameter that needs to be controlled in order to recover submerged aquatic vegetation and biodiversity

\section{3 (Scheffer et al., 1993).}

44 This issue has been approached from a wide range of perspectives, such as the

45 termination of untreated sewage discharges or the improvement in wastewater treatment 46 techniques. In other cases, eutrophic waters have been treated by using different 47 engineered bioremediation technologies, including constructed wetlands (CWs) 48 (Coveney et al., 2002; Wu et al., 2010).

49 The modelling of CW performance was initiated with the development of first-order 50 decay models (Kadlec and Knight, 1996; Stone et al., 2004), which were based on 
input/output data and the treatment processes were considered as a figurative black box. These models were simplifications of the complex wetland processes and more knowledge was needed in order to optimize the performance of CWs. Accordingly, multiple experiments and research have been carried out and a greater level of understanding has been achieved, partly due to the development of mechanistic or process-based models (Min et al., 2011). Mechanistic models use mathematical formulation to represent the processes that affect each variable inside a $\mathrm{CW}$ and are useful to clarify which are the key processes and how they work in CW performance.

An intermediate model between these two types is the autobiotic model developed by Kadlec (1997), which provides a low-level mechanistic explanation of phosphorus removal processes in CWs by using a first order biomass-based rate.

Over the last two decades, a great leap forward in mechanistic models for CWs has taken place (Meyer et al., 2015). Most of them were applied to simulate urban wastewater treatment in subsurface flow CWs (SSFCWs), e.g. Constructed Wetlands 2D (CW2D) (Langergraber, 2001) and Constructed Wetland Model number 1 (CWM1) (Langergraber, et al., 2009), which are based on the mathematical formulation of the Activated Sludge Model series (ASMs) (Henze et al., 2000). Mburu et al., (2012) implemented CWM1 in AQUASIM and one of the most widely used application of models CW2D and CWM1 is the Wetland Module in HYDRUS software (Langergraber and Simunek, 2012). The model FITOVERT (Giraldi et al., 2010) also uses a biochemical module based on ASMs for simulating organic matter and nitrogen in SSFCWs. Likewise, a high level of detail is achieved, e.g. BIO_PORE model (Samsó and Garcia, 2013) is able to simulate biofilm growth and clogging in porous media.

On the other hand, RWQM1 (Reichert et al., (2001)) is a mechanistic model also based on the structure of ASMs models where microalgae performance is simulated in rivers. 
Nevertheless, mechanistic models developed for free water surface constructed wetlands (FWSCWs) are less numerous, and those models developed for SSFCWs or river water quality cannot be directly used in these systems. Mulling (2013) deeply studied suspended particles removal in FWSCWs and determined the changes in the type and nature of these particles throughout the treatment. Besides physical, chemical and biological processes, FWSCWs maximize the interactions with the environment and the biota. In particular, some of the most influential factors in FWSCWs are related to wind action and bioturbation (Onandia et al. 2015), which are not included in the abovementioned models.

Although some mechanistic models were developed for FWSCWs, interactions with biotope and biota are not strongly studied. A remarkable advance is the modelling developed in the stormwater treatment areas of Everglades National Park where particular attention was paid to phosphorus removal (Wang and Mitsch, 2000; Min et al., 2011). Other models were developed to simulate nitrogen, phosphorus and suspended solids from non-point source pollution (Chavan and Dennett, 2008) or from urban wastewater (Wang et al., 2012).

In order to optimize eutrophic water treatment and total suspended solids (TSS) removal in FWSCWs, it is necessary to have available an appropriate mechanistic model where the main components involved are simulated.

This study aims to develop a mechanistic model for FWSCWs treating eutrophic water in order to simulate the removal of TSS and its relation to phytoplankton and total phosphorus. This work is focused on TSS because increasing water transparency is an essential factor in achieving good ecological status in water bodies. The model will facilitate an overview of the CW's performance within its environment since interactions with biota and biotope are included. For this reason, the model is calibrated 
and validated in two full-scale FWSCWs treating hypertrophic water (named FG1 and FG2). These FWSCWs are located in Tancat de la Pipa, a protected area near the eutrophic shallow Lake l'Albufera de València (Spain), where the high concentration of total phosphorus (TP) and TSS hinder the recovery of the good environmental status of the water body.

This model will increase the understanding about the different processes that affect suspended solids, phytoplankton and total phosphorus by bringing to light how they work and to what extent they affect concentrations. In addition, the model could be used as a management and design tool to improve FWSCW's performance.

\section{Methods}

In this section a full appraisal of the mechanistic model is presented. Furthermore, the study site where the calibration and validation were carried out is described and the sensitivity analysis is set forth in detail.

\subsection{Model description}

The proposed model is implemented in the software AQUASIM (Reichert, 1998). The model structure is based on processes reactions which are included in the software as dynamic processes. Components of the model are introduced as state variables and the rest of parameters are introduced as programme, constant, real list or formula variables. The mixed reactor compartment configuration is used and defined by the volume of the wetland, active variables, active processes, initial conditions and inputs. The variableorder Gear integration technique is used to solve the differential equations (Reichert, (1998)). 
124 The model describes the processes, kinetics and stoichiometric coefficients that 125 determine the performance of each component. The mass balance for each component is 126 calculated by Eq. 1:

$$
\frac{\mathrm{d}\left(\mathrm{VC}_{\mathrm{n}}\right)}{\mathrm{dt}}=\mathrm{Q}_{\mathrm{in}} \mathrm{C}_{\mathrm{in}, \mathrm{n}}-\mathrm{Q}_{\text {out }} \mathrm{C}_{\mathrm{n}}+\mathrm{Q}_{\mathrm{rf}} \mathrm{C}_{\mathrm{rf}, \mathrm{n}} \pm \mathrm{Q}_{\mathrm{et}} \mathrm{C}_{\mathrm{et}, \mathrm{n}} \pm \mathrm{Q}_{\mathrm{gr}} \mathrm{C}_{\mathrm{gr}, \mathrm{n}}+\mathrm{Vr}_{\mathrm{n}} \mathrm{C}_{\mathrm{n}}
$$

127

where $\mathrm{n}=1,2 \ldots \mathrm{m}, m$ is the total number of components, $\mathrm{V}(\mathrm{L})$ is the water volume, $\mathrm{t}(\mathrm{s})$ is time, $\mathrm{C}_{\mathrm{n}}\left(\mathrm{mg} \mathrm{L}^{-1}\right)$ is the outlet concentration of the component $n, \mathrm{Q}_{\text {in }}\left(\mathrm{L} \mathrm{s}^{-1}\right)$ is the inlet flow, $\mathrm{C}_{\mathrm{in}, \mathrm{n}}\left(\mathrm{mg} \mathrm{L}^{-1}\right)$ is the inlet concentration of the component $n$, $\mathrm{Q}_{\text {out }}\left(\mathrm{L} \mathrm{s}^{-1}\right)$ is the outlet flow, $\mathrm{Q}_{\mathrm{rf}}\left(\mathrm{L} \mathrm{s}^{-1}\right)$ is the direct rainfall flow entering to the system, $\mathrm{C}_{\mathrm{rf}, \mathrm{n}}\left(\mathrm{mg} \mathrm{L}^{-1}\right)$ is the concentration in the rainfall of the component $n, \mathrm{Q}_{\mathrm{et}}\left(\mathrm{L} \mathrm{s}^{-1}\right)$ is the flow that leaves the system due to evapotranspiration, $\mathrm{C}_{\mathrm{et}, \mathrm{n}}\left(\mathrm{mg} \mathrm{L}^{-1}\right)$ is the concentration in the evapotranspiration of the component $n, \mathrm{Q}_{\mathrm{gr}}\left(\mathrm{L} \mathrm{s}^{-1}\right)$ is accounting for the gains or losses of the system by percolation to groundwater, $\mathrm{C}_{\mathrm{gr}, \mathrm{n}}\left(\mathrm{mg} \mathrm{L}^{-1}\right)$ is the concentration in the percolation flow of the component $n$ and $\mathrm{r}_{\mathrm{n}}\left(\mathrm{d}^{-1}\right)$ is the reaction rate for the component $n$. Concentration of the component $n$ in the evapotranspiration flow is assumed to be equal to zero. $r_{n}$ is calculated as shown in Eq. 2:

$$
r_{n}=\sum_{j=1}^{R} v_{n, j} r_{j}
$$

where $j=1,2 \ldots \mathrm{R}, \mathrm{R}$ is the total number of processes, $v_{\mathrm{n}, \mathrm{j}}$ is the stoichiometric factor for component $n$ and process $j$, and $\mathrm{r}_{\mathrm{j}}\left(\mathrm{d}^{-1}\right)$ is the reaction rate for process $j$.

Components included in the model are shown in Table 1. Phytoplankton was included in order to study the contribution of its dry weight to the TSS budget and due to its relevance in the eutrophication process, and phosphorus was introduced because its 

nutrient in eutrophic water.

\section{Table 1. Description of the components included in the model.}

\begin{tabular}{|c|c|c|}
\hline Component & Description & Unit \\
\hline TIP & Total inorganic phosphorus. & $\mathrm{mg} \mathrm{P} \mathrm{L}^{-1}$ \\
\hline $\mathrm{OP}$ & Organic phosphorus. & $\operatorname{mg~P~L} L^{-1}$ \\
\hline $\mathrm{P}_{\text {int }}$ & Phosphorus accumulated inside the phytoplankton cells. & $\operatorname{mg~P~mg~Chl~} a^{-1}$ \\
\hline$X_{P}$ & Phytoplankton biomass. & $\operatorname{mg} \mathrm{Chl} a \mathrm{~L}^{-1}$ \\
\hline $\mathrm{X}_{\mathrm{TSS}}$ & Total suspended solids. & $m g d w L^{-1}$ \\
\hline
\end{tabular}

150 The component $\mathrm{X}_{\mathrm{P}}$ represents the entire phytoplankton biomass and TP was calculated as shown in Eq. 3, where $\mathrm{i}_{\mathrm{PXp}}\left(\mathrm{mg} \mathrm{P} \mathrm{mg} \mathrm{Chl} a^{-1}\right)$ is the content of phosphorus in phytoplankton tissues:

$$
\mathrm{TP}=\mathrm{TIP}+\mathrm{OP}+\mathrm{P}_{\text {int }} \cdot \mathrm{X}_{\mathrm{P}}+\mathrm{X}_{\mathrm{P}} \cdot \mathrm{i}_{\mathrm{PXp}}
$$

154 Phosphorus is divided into organic and inorganic forms. OP concerns both particulate and dissolved forms and is subjected to the mineralization process (Figure 1). Inorganic phosphorus is divided into DIP (dissolved inorganic phosphorus) and PIP (particulate inorganic phosphorus) through adsorption/desorption equilibrium processes, which are linked to $X_{\text {TSS }}$ concentration depending on the partition coefficient $\left(K_{d}, \mathrm{~L} \mathrm{mg}^{-1}\right)$ (Eq. 4). Luxury uptake of phosphorus is considered so $\mathrm{X}_{\mathrm{P}}$ stores DIP intracellularly following the mathematical expression used by Onandia et al. (2015). The capacity of $X_{P}$ for internal phosphorus storage is limited, so DIP uptake will only occur when P internally stored $\left(\mathrm{P}_{\text {int }}\right)$ is lower than the maximum storage capacity. Afterwards, $\mathrm{P}_{\text {int }}$ is used to

163 form cellular tissue when phytoplankton grows. When $X_{P}$ decays, its content of 164 phosphorous ( $\mathrm{i}_{\mathrm{PXp}}$ and $\mathrm{P}_{\mathrm{int}}$ ) is released into the water column. Following the kinetic rate 
165 for internally stored compounds in ASM2 (Henze et al., 2000), the release of $\mathrm{P}_{\text {int }}$ is 166 modelled as an individual process. Diffusion of DIP occurs between the top $10 \mathrm{~cm}$ of

167 sediment layer and water column. It was modelled by modifying Fick's first law by a

168 coefficient of variation in the diffusion between water and sediments $\left(\mathrm{K}_{\text {difu sed }}\right)$ that

169 includes the effects of porosity and tortuosity of the sediment.

$170 \mathrm{X}_{\mathrm{TSS}}$, OP and PIP are subjected to sedimentation and resuspension processes, and $\mathrm{X}_{\mathrm{P}}$ is 171 affected by sedimentation too, which are affected by emergent vegetation cover (VC).

172 Based on the results obtained by Paudel and Jawitz (2012), DIP uptake by emergent

173 vegetation was decided to be excluded from the model. It was considered that the 174 enhancement that would be achieved in model simulations was not worthwhile with the 175 increase in model complexity and uncertainty linked to additional parameters.

$$
\mathrm{DIP}=\mathrm{TIP}-\mathrm{PIP}=\mathrm{TIP} \cdot \mathrm{f}_{\mathrm{d}}=\frac{1}{1+\mathrm{k}_{\mathrm{d}} \cdot \mathrm{X}_{\mathrm{TSS}}}
$$

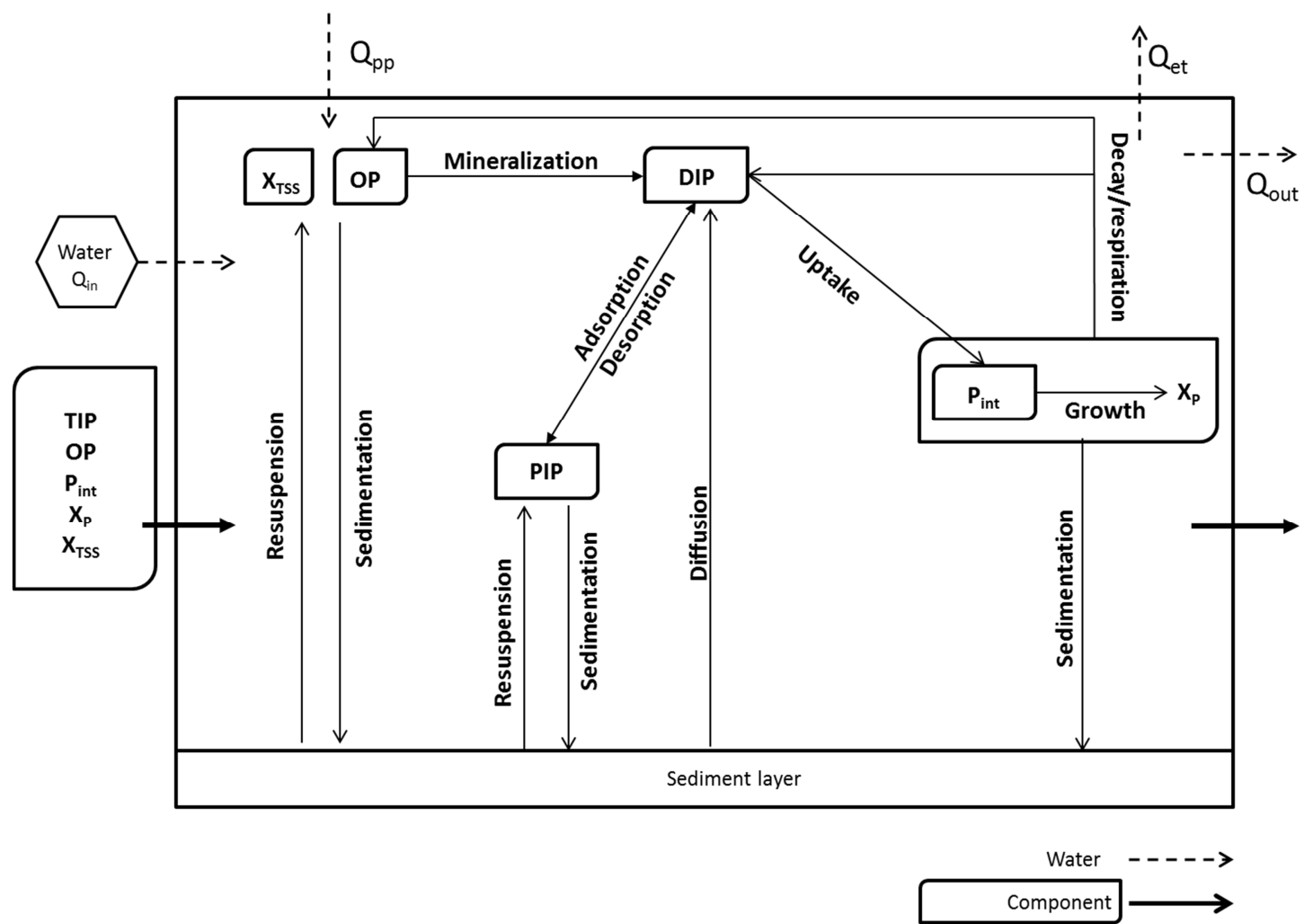
Figure 1. Schematic diagram of the model developed in this study. 
Water velocity in FWSCWs is usually too low to cause resuspension so wind action is usually the most important factor involved in resuspension (Weyhenmeyer et al., 1997; Douglas and Rippey, 2000), adding bioturbation caused by avifauna and in some cases by icthyofauna (Kadlec and Wallace, 2009). Resuspension modelling varies from simple models where zero-order kinetics is used (Wang and Mitsch, 2000), to very detailed models where an exhaustive sediment characterization is needed (Chapra, 1997). In order to find the balance between process comprehensiveness and field data obtained, resuspension is divided into two independent processes: resuspension caused by wind and resuspension caused by bioturbation.

In relation to wind resuspension, a necessary condition for this process is that the wavelength of the wave caused by wind needs to have a magnitude at least double the water depth. Thereby, it is possible to obtain the minimum wind speed to cause resuspension $\left(\mathrm{W}_{0}, \mathrm{~m} \mathrm{~s}^{-1}\right)$ using an empirical equation developed for coastal oceanography that is commonly used for quantitative analyses about resuspension in shallow lakes (Nagid et al., 2001):

$$
\mathrm{L}=1.56\left[0.77 \cdot \mathrm{W} \cdot \tanh \left[0.077\left(\frac{9.8 \cdot \mathrm{F}}{\mathrm{W}^{2}}\right)^{0.25}\right]\right]^{2}
$$

where $\mathrm{L}(\mathrm{m})$ is wavelength, $\mathrm{W}\left(\mathrm{m} \mathrm{s}^{-1}\right)$ is wind speed and $\mathrm{F}(\mathrm{m})$ is the fetch. The fetch is the maximum distance that can be uniformly affected by speed and wind direction in a water body, and it is calculated taking into account wind direction, length and width of the FWSCW. According to the model proposed by Cózar et al. (2005) for TSS and turbidity in shallow lakes, TSS resuspension caused by wind is modelled through a correlation with daily maximum wind speed observed data (Eq. 6). Resuspension also releases P from sediment to the water column (Søndergaard et al., 1992), which depends 
202 on the $\mathrm{P}$ content in the sediments $\left(\mathrm{i}_{\text {Psed }}, \mathrm{mg} \mathrm{P} \mathrm{mg} \mathrm{dw}{ }^{-1}\right)$ and is added as OP or PIP 203 depending on $\mathrm{F}_{\mathrm{pr}}$ (fraction of resuspended $\mathrm{P}$ recycled to $\mathrm{OP}$ ) (Eq. 7 and 8). 204 Resuspension by wind is not a dynamic process, but it is used to calculate the concentrations that this phenomenon causes by adding sediment to the water column, so

206 it is considered as an input to the system.

207 The trapping effect of particulate components by emergent vegetation is introduced in resuspension kinetics. According to Hosokawa and Horie (1992), an improvement in TSS removal was demonstrated in laboratory channels and CWs planted with Phragmites australis. Vegetation cover (i.e. the fraction of the CW surface covered by

211 the projection of the aerial part of the plants) and $\mathrm{K}_{\mathrm{veg}}$ resus (coefficient for trapping by 212 emergent VC in resuspension processes) were used to model the effect of emergent vegetation in resuspension processes through the expression $\left(1-\mathrm{VC} \cdot \mathrm{K}_{\mathrm{veg} \text { resus }}\right)(\mathrm{Eq} .6-8)$. Resuspension by wind is zero when the $\mathrm{CW}$ surface is completely vegetated $(\mathrm{VC}=1)$ and is maximum when no vegetation is present $(\mathrm{VC}=0)$.

216 Equations 6-8 were used to calculate $\mathrm{X}_{\mathrm{TSS}}$, OP and PIP entering to the system by wind resuspension:

$$
\mathrm{X}_{\mathrm{TSS} \mathrm{res}}\left(\mathrm{mg} \mathrm{l}^{-1}\right)=\alpha \cdot \mathrm{W}^{\beta} \delta\left(\mathrm{W}, \mathrm{W}_{\mathrm{o}}\right)\left(1-\mathrm{VC} \cdot \mathrm{K}_{\mathrm{veg} \mathrm{resus}}\right)
$$

218

$$
\mathrm{OP}_{\text {res }}\left(\mathrm{mg} \mathrm{P} \mathrm{l}^{-1}\right)=\alpha \cdot \mathrm{W}^{\beta} \delta\left(\mathrm{W}, \mathrm{W}_{\mathrm{o}}\right)\left(1-\mathrm{VC} \cdot \mathrm{K}_{\mathrm{veg} \mathrm{resus}}\right) \cdot \mathrm{i}_{\text {Psed }} \cdot \mathrm{F}_{\mathrm{pr}}
$$

$$
\mathrm{PIP}_{\mathrm{res}}\left(\mathrm{mg} \mathrm{P} \mathrm{l}^{-1}\right)=\alpha \cdot \mathrm{W}^{\beta} \delta\left(\mathrm{W}, \mathrm{W}_{\mathrm{o}}\right)\left(1-\mathrm{VC} \cdot \mathrm{K}_{\mathrm{veg} \mathrm{resus}}\right) \mathrm{i}_{\mathrm{Psed}} \cdot\left(1-\mathrm{F}_{\mathrm{pr}}\right)
$$

221 where $\mathrm{W}\left(\mathrm{m} \mathrm{s}^{-1}\right)$ is maximum daily wind speed, $\alpha$ and $\beta$ are parameters to be calibrated, 222 while $\delta\left(\mathrm{W}, \mathrm{W}_{0}\right)$ is a step function that determines the periods when the wind-induced waves cause resuspension ( $\delta=0$ if $\mathrm{W}<\mathrm{W}_{\mathrm{o}}$ and $\delta=1$ if $\mathrm{W}>\mathrm{W}_{\mathrm{o}}$ ). 

FWSCWs.

\begin{tabular}{lll}
\hline RF & Description & Examples of specie \\
\hline 10 & Large birds that actively remove the substrate to & Phoenicopterus spp \\
& feed. \\
9 & $\begin{array}{l}\text { Medium-sized birds that actively remove the } \\
\text { substrate to feed. }\end{array}$
\end{tabular}

8 Large fishing birds that remove the substrate.

Phalacrocorax carbo

7 Medium-sized waterfowl that feed on the Anas platyrhynchos, Anas strepera, Ardea substrate; large fisher herons. cinerea, Egretta alba, Tadorna tadorna

6 Medium-sized waterfowl that do not feed on the Anas acuta, Fulica atra, Fulica cristata, substrate; herons that feed on the substrate; large Limosa limosa, Netta rufina, Plegadis waders; medium-sized waders that remove the falcinellus, Recurvirostra avosetta substrate to feed.

$5 \quad$ Fisher herons; large size rallids; diving waterfowl Ardea purpurea, Aythya ferina, Porphyrio that feed on the substrate. porphyrio

4 Small waterfowl that feed on the surface; waders Anas clypeata, Anas crecca, Anas penelope, and medium-sized rallids.

Anas querquedula, Gallinula chloropus, Himantopus himantopus, Philomachos pugnax, Tringa erythropus, Tringa nebularia, Tringa stagnatilis, Vanellus vanellus

3 Medium-sized fisher herons; medium and large Ardeola ralloides, Botaurus stellaris, Bubulcus swimming birds that do not remove the substrate; medium-sized fisher herons; great diving waterfowl that do not feed the substrate.

ibis, Egretta garzetta, Ixobrychus minutus, Larus audouinii, Larus fuscus, Larus michahellis, Nycticorax nycticorax, Podiceps cristatus

2 Waterfowl divers that do not feed on the Podiceps nigricollis, Tachybaptus ruficollis substrate.

1 Small waders; swimmer birds that do not remove Actitis hypoleucos, Calidris alpina, Calidris the substrate.

ferruginea, Calidris minuta, Calidris temminckii, Charadrius alexandrinus, Charadrius dubius, Charadrius hiaticula, Gallinago gallinago, Larus genei, Larus ridibundus, Lymnocryptes minimus, Porzana parva, Rallus aquaticus, Tringa glareola, Tringa ochropus, Tringa totanus

0 Fishing birds that only affect waterbodies for Chlidonias hybrida, Chlidonias leucopterus, fishing hauls; aquatic birds that do not feed or rest on it.

Chlidonias niger, Gelochelidon nilotica, Glareola pratincola, Mycteria ibis, Sterna hirundo, Sternula albifrons 
227 With regard to resuspension caused by bioturbation, bird activity is an influencing 228 factor in sediment resuspension that increases TSS concentration in CWs (Greenway, 2010; Martin et al., 2013). The amount of resuspension produced depends on the density and type of birds. Field observations reveal that some groups of birds such as

231 passerine birds, that are small and light, have no impact on water quality. Others like

232 flamingo (Phoenicopterus spp.) cause considerable sediment resuspension due to 233 filtering action while feeding (Comín et al., 1997; Glassom and Branch, 1997). 234 According to these observations, avifauna is divided into different groups of birds (i) depending on their affection to sediment resuspension and consequently a resuspension factor $\left(\mathrm{RF}_{\mathrm{i}}\right)$ is assigned to each group (Table 2). This classification takes into account bird size, feeding habits and ways of movement within the $\mathrm{CW}$ in order to estimate their impact on sediment resuspension.

The effect of vegetation cover in avifauna resuspension is modelled as in resuspension caused by wind.

Before introducing a mathematical expression for modelling resuspension caused by 242 icthyofauna, an estimation of the magnitude of this process in Tancat de la Pipa, the area where the model was calibrated and validated, was carried out. The highest density of fishes was detected in the so-called Reserve Lagoon (Figure 1), where $33.33 \mathrm{~kg} \mathrm{ha}^{-1}$ were counted in April 2014, mainly Cyprinus carpio (data not published). Considering that $77.24 \cdot 10^{-4} \mathrm{mg} \mathrm{L}^{-1}$ of TSS can be resuspended per each $\mathrm{kg}$ of Cyprinus carpio 247 contained in one hectare (Tsanis et al., 1998), it was calculated that $0.26 \mathrm{mg} \mathrm{L}^{-1}$ of TSS 248 could be resuspended by icthyofauna. Comparing with average TSS concentrations in Tancat de la Pipa (Martin et al, 2013), this quantity means less than 2\% of TSS entering and leaving these FWSCWs. Given the low impact of icthyofauna resuspension in the 
system where the model was calibrated and validated, this process was not included in

252

253

254

255

256

257

258

260

261

262

263

264

265

266

$$
\mathrm{K}_{\mathrm{e}}=\mathrm{K}_{\mathrm{e} 0}+\mathrm{axp}_{\mathrm{Xp}} \cdot \mathrm{X}_{\mathrm{P}}
$$
the model. concentration (Eq. 10).

Influence of vegetation cover on sedimentation processes of $\mathrm{X}_{\mathrm{TSS}}$ and the particulate fractions of TIP and OP was described using the expression $\left(1+\mathrm{VC} \cdot \mathrm{K}_{\mathrm{veg}} \mathrm{sed}\right)$, where $\mathrm{K}_{\mathrm{veg} \text { sed }}$ is the coefficient for trapping by emergent $\mathrm{VC}$ in sedimentation processes. The higher the vegetation cover, the greater the effect of trapping.

Regarding phytoplankton biomass, it is usually measured as the concentration of chlorophyll $a$ and its contribution to TSS concentration depends on its ratio dry weight:Chl $a$ (i $\left.\mathrm{i}_{\text {TSSXp }}\right)$. Light limitation in phytoplankton growth kinetics $\left(\mathrm{G}_{\mathrm{L}}\right)$ is simulated as described in Di Toro et al., (1971), where diurnal surface-light variation, light attenuation with depth and photoinhibition are included. Emergent vegetation cover is taken into account in order to model its influence in incident daylight intensity (Eq. 9). Spatial variation of light down through the water column is modelled by the Beer-Lambert law and the extinction coefficient is determined in accordance to $X_{P}$

$$
\mathrm{G}_{\mathrm{L}}=\frac{2.718 \cdot \mathrm{f}}{\mathrm{k}_{\mathrm{e}} \cdot \mathrm{H}}\left(\exp \left(-\frac{\mathrm{I}_{0}}{\mathrm{I}_{\mathrm{s}}} \mathrm{e}^{-\mathrm{k}_{\mathrm{e}} \cdot \mathrm{H}}\right)-\exp \left(-\frac{\mathrm{I}_{0}}{\mathrm{I}_{\mathrm{s}}}\right)\right) \cdot(1-\mathrm{VC})
$$

where $\mathrm{f}$ is the photoperiod (the fraction of daylight), $\mathrm{K}_{\mathrm{e}}\left(\mathrm{m}^{-1}\right)$ is the extinction coefficient, $\mathrm{H}(\mathrm{m})$ is water depth, $\mathrm{I}_{0}\left(\mathrm{ly} \mathrm{d}^{-1}\right)$ is the average incident daylight intensity, $\mathrm{I}_{\mathrm{S}}$ $\left(\mathrm{y} \mathrm{d}^{-1}\right)$ is the saturating light intensity, $\mathrm{K}_{\mathrm{e} 0}\left(\mathrm{~m}^{-1}\right)$ is the light attenuation coefficient of water and $\operatorname{axp}_{\mathrm{xp} \mathrm{m}}\left(\mathrm{L} \mathrm{m}^{-1} \mathrm{~m}^{-1}\right)$ is the specific light attenuation coefficient of phytoplankton. 
272 Temperature influences OP mineralization, DIP diffusion, growth, decay and respiration

273 of phytoplankton, and it is simulated with the Arrhenius equation (Eq. 11).

$$
\mathrm{k}_{\mathrm{T}}=\mathrm{k}_{20} \theta^{\mathrm{T}-20}
$$

274

275 where $k_{T}\left(d^{-1}\right)$ is process rate at temperature $T, k_{20}\left(d^{-1}\right)$ is process rate at $20^{\circ} \mathrm{C}, \theta$ is 276 temperature coefficient and $\mathrm{T}\left({ }^{\circ} \mathrm{C}\right)$ is temperature.

277 Processes described in Table 3 are dynamic processes, while adsorption/desorption is a 278 chemical equilibrium process that determines the relation between the measured 279 component DIP and the calculated component PIP, in accordance with the partitioning 280 coefficient, $\mathrm{K}_{\mathrm{d}}$.

281 Parameters used are given in Appendix A. 
Table 3. Stoichiometric matrix and processes rates in the model.

\begin{tabular}{|c|c|c|c|c|c|c|c|}
\hline & $\begin{array}{l}\text { Component } \rightarrow \\
\text { Process } \downarrow\end{array}$ & TIP & $\mathrm{P}_{\mathrm{int}}$ & $\mathrm{OP}$ & $\mathrm{X}_{\mathrm{P}}$ & $\mathrm{X}_{\mathrm{TSS}}$ & $\mathrm{r}$ \\
\hline 1. & Mineralization of OP & 1 & & -1 & & & $\mathrm{~K}_{\operatorname{min~OP}} \theta_{\operatorname{min~OP}}^{\mathrm{T}-20}\left(\frac{\mathrm{DO}}{\mathrm{DO}+\mathrm{k}_{\mathrm{DO}}}\right) \mathrm{OP}$ \\
\hline 2. & Phosphorus uptake by $X_{P}$ & $-X_{P}$ & 1 & & & & $P_{\text {max uptake }}\left(\frac{P_{\max }-P_{\text {int }}}{P_{\max }-P_{\min }}\right)\left(\frac{\text { TIP } \cdot f_{d}}{k_{\text {DIPup }}+\text { TIP } \cdot f_{d}}\right)$ \\
\hline 3. & Growth of $X_{P}$ & & $-\mathrm{i}_{\mathrm{PXP}} / \mathrm{X}_{\mathrm{P}}$ & & 1 & $\mathrm{i}_{\mathrm{TSSX}}$ & $G_{\max } \theta_{G}^{T-20}\left(\frac{P_{\text {int }}-P_{\min }}{P_{\max }-P_{\min }}\right) X_{P} \cdot G_{L}$ \\
\hline 4. & Decay of $X_{P}$ & $\mathrm{i}_{\mathrm{PXP}}\left(1-\mathrm{F}_{\mathrm{op}}\right)$ & & $\mathrm{i}_{\mathrm{PXp}} \cdot \mathrm{F}_{\mathrm{op}}$ & -1 & $-\mathrm{i}_{\mathrm{TSSX}}$ & $\mathrm{K}_{\mathrm{r}} \theta_{\mathrm{r}}^{\mathrm{T}-20} \mathrm{X}_{\mathrm{P}}$ \\
\hline 5. & Lysis of $\mathrm{P}_{\mathrm{int}}$ & $\mathrm{X}_{\mathrm{P}}$ & -1 & & & & $\mathrm{~K}_{\mathrm{r}} \theta_{\mathrm{r}}^{\mathrm{T}-20} \mathrm{P}_{\mathrm{int}}$ \\
\hline 6. & Respiration of $X_{P}$ & $\mathrm{i}_{\mathrm{PXP}}\left(1-\mathrm{F}_{\mathrm{op}}\right)$ & & $\mathrm{i}_{\mathrm{PXp}} \cdot \mathrm{F}_{\mathrm{op}}$ & -1 & $-\mathrm{i}_{\mathrm{TSSX}}$ & $\mathrm{K}_{\text {resp }} \theta_{\text {resp }}^{\mathrm{T}-20} \frac{\mathrm{DO}}{\mathrm{k}_{\mathrm{DO} \mathrm{Xp}}+\mathrm{DO}} \mathrm{X}_{\mathrm{P}}$ \\
\hline 7. & Sedimentation of $X_{P}$ & & & & -1 & $-\mathrm{i}_{\mathrm{TSSX}}$ & $\left(\frac{v_{\text {SXp }}}{H}\right) X_{P}$ \\
\hline 8. & Sedimentation of $\mathrm{X}_{\mathrm{PIP}}$ & -1 & & & & & $\left(\frac{\mathrm{v}_{\mathrm{sTIP}}}{\mathrm{H}}\right) \operatorname{TIP}\left(1-\mathrm{f}_{\mathrm{d}}\right)\left(1+\mathrm{VC} \cdot \mathrm{K}_{\text {veg sed }}\right)$ \\
\hline 9. & Sedimentation of OP & & & -1 & & & $\left(\frac{\mathrm{V}_{\mathrm{sOP}}}{\mathrm{H}}\right) \mathrm{OP} \cdot \mathrm{f}_{\mathrm{POP}}\left(1+\mathrm{VC} \cdot \mathrm{K}_{\mathrm{veg} \mathrm{sed}}\right)$ \\
\hline 10. & Sedimentation of $\mathrm{X}_{\mathrm{TSS}}$ & & & & & -1 & $\left(\frac{\mathrm{V}_{\mathrm{sTSS}}}{\mathrm{H}}\right) \mathrm{X}_{\mathrm{TSS}}\left(1+\mathrm{VC} \cdot \mathrm{K}_{\mathrm{veg} \mathrm{sed}}\right)$ \\
\hline 11. & Resuspension by avifauna & $\mathrm{i}_{\text {Psed }} \cdot\left(1-\mathrm{F}_{\mathrm{pr}}\right)$ & & $\mathrm{i}_{\text {Psed }} \cdot \mathrm{F}_{\mathrm{pr}}$ & & 1 & $\mathrm{~K}_{\mathrm{avi}} \frac{\sum_{\mathrm{i}=0}^{\mathrm{i}} \mathrm{N}_{\mathrm{i}} \cdot \mathrm{RF}_{\mathrm{i}}}{\mathrm{A}}\left(1-\mathrm{VC} \cdot \mathrm{K}_{\mathrm{veg} \text { res }}\right)$ \\
\hline 12. & Diffusion & 1 & & & & & $\mathrm{D}_{0 \mathrm{P}} \cdot \mathrm{K}_{\text {difu sed }} \cdot \theta_{\text {difu }}^{\mathrm{T}-20}\left(\mathrm{P}_{\mathrm{sed}}-\mathrm{PIT} \cdot \mathrm{f}_{\mathrm{d}}\right) \frac{1}{0.1 \cdot \mathrm{H}}$ \\
\hline
\end{tabular}




\subsection{Study site and experimental data}

285 The developed model was applied on the FWSCWs situated in Tancat de la Pipa, which 286 is located at $39^{\circ} 21^{\prime} 51^{\prime \prime} \mathrm{N}-0^{\circ} 20^{\prime} 47^{\prime \prime} \mathrm{O}$ in Valencia, Spain. This set of CWs treats 287 eutrophic fresh water from the adjacent lake known as L'Albufera and is divided into 288 different units (Figure 2). Water continuously enters the FWSCW named as FG1 from 289 point P0 and moves by gravity flow. FWSCWs FG1 $\left(13509 \mathrm{~m}^{2}\right)$ and FG2 $\left(18240 \mathrm{~m}^{2}\right)$ 290 work in series and in both cases, water flows through four sluices of $0.3 \mathrm{~m}$ width, 291 spaced every $30 \mathrm{~m}$. Water depths in both systems remain between $0.15-0.25 \mathrm{~m}$.

292 Percolation was demonstrated to be negligible (Martin et al., 2013). Both units were 293 planted with cattails in January-February 2009, with a density of $1 \mathrm{stem} \mathrm{m}^{-2}$. FG1 was 294 harvested in October 2009, vegetation cover in FG2 started to drop in May 2010 and emergent vegetation was not recovered in any unit.

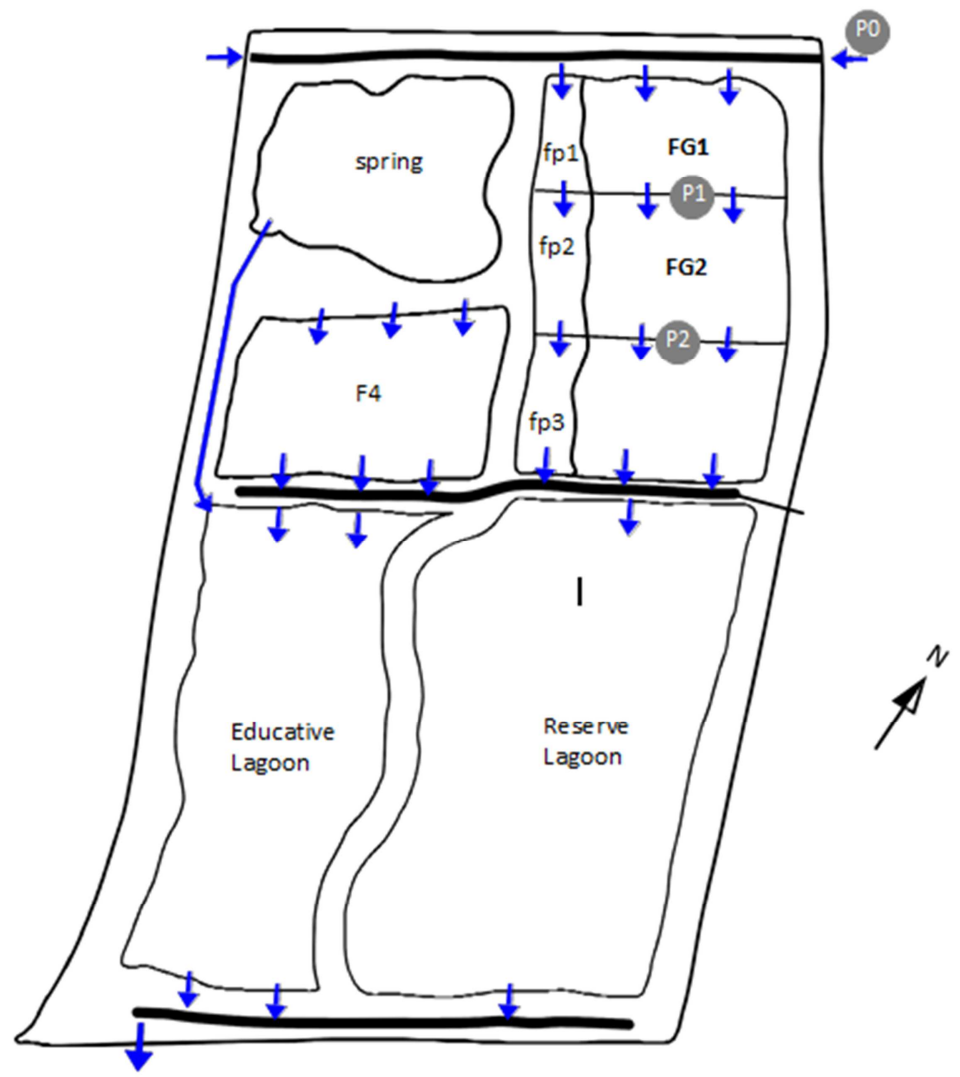

Figure 2. Schematic representation of the study site. 
298 Monitoring was carried out from April 2009 to April 2012. During this period the 299 system was operated with hydraulic loading rates (HLR) between 26 and $209 \mathrm{~m} \mathrm{year}^{-1}$.

300 The inlet was interrupted during October-November 2009, March and August 2011 due 301 to maintenance operations. More details about the FWSCWs configuration and 302 operation can be seen in Martín et al. (2013).

303 Hydraulic monitoring was carried out by measuring water depths and velocities in each inlet sluices. Gauging sections consist of rectangular sections where free surface flow exists and velocities are gauged with a mini current meter (Rivers-Moore et al., 2006). Water samples were collected in points P0, P1 and P2 every two weeks since April 2009 to October 2011, and monthly from November 2011 to April 2012 ( $n=64)$. These samples were analysed for total suspended solids (TSS), chlorophyll $a$ (Chl $a$ ), total phosphorus (TP), phosphates $\left(\mathrm{PO}_{4}{ }^{3-}-\mathrm{P}\right)$ and total and soluble chemical oxygen demand (TCOD and SCOD) (Martin et al., 2013).

311 They were collected between $9.00 \mathrm{~h}$ and $14.00 \mathrm{~h}$ at a depth of $0.1 \mathrm{~m}$ with $2 \mathrm{~L}$ bottles, 312 transported and preserved at $4^{\circ} \mathrm{C}$ until analysis took place, no later than $24 \mathrm{~h}$ after 313 sampling. In all these samples TP and $\mathrm{PO}_{4}{ }^{3-}-\mathrm{P}$ were analysed using the Spectroquant® 314 Analysis System by Merck, TSS was determined according to APHA (1991) and Chl $a$ was obtained by extracting photosynthetic pigments using acetone $90 \%$ as solvent, absorbance values were determined with a spectrophotometer, and by using the equations devised by Jeffrey and Humphrey (1975). Dissolved oxygen (DO), conductivity, $\mathrm{pH}$ and temperature were measured in situ using portable field measurement equipment (WTW-Multi 340i).

320 Following Eq. 3, phosphorus fractioning in the water samples was carried out: DIP concentration was assumed to be measured phosphates, OP was equivalent to $1 \%$ of TCOD, $\mathrm{P}_{\text {int }}$ was assumed to be equal to $\mathrm{P}_{\min }$ and PIP was calculated as the difference 
323 between $\mathrm{TP}$ and the rest of fractions. Initial conditions for the components 324 concentrations are showed in Table 4:

Table 4. Initial conditions for the component concentrations in FWSCWs FG1 and FG2.

\begin{tabular}{clcc}
\hline \multirow{2}{*}{ Component } & \multirow{2}{*}{ Units } & \multicolumn{2}{c}{ Initial conditions } \\
\cline { 3 - 4 } & & FG1(calibration) & FG2 (validation) \\
\hline TIP & m P $^{-1}$ & 0.401 & 0.073 \\
OP & m P $^{-1}$ & 0.029 & 0.030 \\
$\mathrm{P}_{\text {int }}$ & ${\text { mg P mg Chl } a^{-1}}_{\mathrm{X}_{\mathrm{P}}}{\mathrm{mg} \mathrm{Chl} a \mathrm{~L}^{-1}}_{\mathrm{X}_{\mathrm{TSS}}}$ & 0.520 & 0.520 \\
$\mathrm{mg} \mathrm{L}^{-1}$ & 0.007 & 0.001 \\
\hline
\end{tabular}

Phosphorus content in sediments ( $\mathrm{i}_{\mathrm{Psed}}$ ) was measured by extracting $\mathrm{P}$ with $\mathrm{HNaCO}_{3}$ and analysing the extract by spectrophotometric method based on phosphate-molybdate complex (ISO 11263:1994).

Rainfall and evapotranspiration data were obtained from a nearby meteorological station located in Picassent (10 km west of FWSCWs), which belongs to a national agricultural research centre (IVIA, http://riegos.ivia.es/). Data related to wind (mean speed, maximum speed and wind direction), photoperiod and average incident daylight intensity were also obtained from this station. The fetch was calculated considering that the FWSCWs are orientated in a NW direction, that the prevailing wind direction observed in the meteorological station is East (29\%) and that resuspension occurs in any point of the water body. The fetch was established to be the half of the width: $72 \mathrm{~m}$ in FG1 and $80 \mathrm{~m}$ in FG2. Using Eq. 5, $\mathrm{W}_{0}$ was calculated to be $3.2 \mathrm{~m} \mathrm{~s}^{-1}$ in FG1 and $2.5 \mathrm{~m}$ $340 \quad \mathrm{~s}^{-1}$ in $\mathrm{FG} 2$.

341 The abundance of each waterfowl species in the FWSCW was counted every two weeks from September 2009 to April 2012. Censuses were performed using a telescope during

343 the first three hours after sunrise and during each session the same transect was

344 surveyed; several observation points were traced in order to ensure a complete census in the CWs. 
346 Emergent vegetation cover was estimated through fortnightly in situ observation and 347 aerial images examination.

348 In order to implement the developed model in FG1 and FG2 FWSCWs, the hydraulic 349 operation of the systems needed to be simulated. A water mass balance was used for 350 accomplishing this aim but with no deeper purpose.

351 Each FWSCW was modelled as a non-dimensional element and therefore the components presented uniform values in the entire compartment and in the outlet. Following Harter and Mitsch (2003), the hydraulic sub-model was based on site data and it was not altered for any of the simulations. The water mass balance was calculated by the dynamic water budget approach and changes in the water volume were strictly due to changes in the water depth:

$$
Q_{\text {out }}=Q_{\text {in }}+Q_{\text {rf }}-Q_{\text {et }} \pm Q_{\text {gr }}-\frac{d V}{d t}
$$

\subsection{Calibration and validation of the model}

Calibration was carried out in FG1 FWSCW and validation in FG2 FWSCW.

Calibration of model parameters was carried out by adjusting their values in order to obtain the best fit between simulated and observed data (April 2009-April 2012).

The suitability of the hydraulic operation representation was determined by using the conservative variable conductivity as a natural tracer since its concentration is not affected by any reactive process and its evolution can be directly linked to the hydraulic performance of the system (Schmidt et al., 2012). Eq. 1 and 12 were applied to conductivity in order to obtain simulated values. The goodness of the adjustment between observed and simulated values was evaluated using the Nash-Sutcliffe efficiency coefficient (NSE, Eq. 13). Values between 0.0 and 1.0 are generally 
considered as acceptable adjustments while values lower than 0.0 indicate that the

370 residual variance obtained from simulated data is greater than the data variance.

$$
\mathrm{NSE}=1-\left\lceil\frac{\sum_{\mathrm{i}=1}^{\mathrm{n}}\left(\mathrm{Y}_{\mathrm{i}}^{\mathrm{obs}}-\mathrm{Y}_{\mathrm{i}}^{\mathrm{sim}}\right)^{2}}{\sum_{\mathrm{i}=1}^{\mathrm{n}}\left(\mathrm{Y}_{\mathrm{i}}^{\mathrm{obs}}-\mathrm{Y}_{\mathrm{i}}^{\mathrm{mean}}\right)^{2}}\right\rceil
$$

371

372 where $Y_{i}{ }^{\text {obs }}$ and $Y_{i}^{\text {sim }}$ are the $i$ th datum for the observed and simulated value and $Y^{\text {mean }}$ is

373 the mean of the observed data.

374 The value of the root mean square error (RMSE, Eq. 14) was used to evaluate the 375 adjustment of the model by comparing simulated and observed outlet concentrations:

$$
\operatorname{RMSE}=\sqrt{\frac{\sum_{\mathrm{i}=1}^{\mathrm{n}}\left(\mathrm{Y}_{\mathrm{i}}^{\mathrm{obs}}-\mathrm{Y}_{\mathrm{i}}^{\text {sim }}\right)^{2}}{\mathrm{n}}}
$$

376 where $n$ is the total number of observations.

\subsection{Sensitivity analysis}

The sensitivity of the developed model was studied in order to find out the most influential parameters in output concentrations of the components. It was carried out in AQUASIM, where linear sensitivity functions of arbitrary variables are calculated with respect to each of the parameters included in the analysis (Reichert, 1998). The absolute-relative sensitivity $\left(\delta_{\mathrm{y}, \mathrm{p}}^{\mathrm{a}, \mathrm{r}}\right)$ function of AQUASIM was used (Eq. 15), which measures the absolute change is an arbitrary variable calculated by AQUASIM, $y$, for a $100 \%$ change in any parameter of interest, $p$. This makes quantitative comparisons of the different parameters on a common variable possible. The 33 parameters included in the stoichiometric matrix were studied.

$$
\delta_{y, p}^{a, r}=p \frac{\partial y}{\partial p}
$$




\section{Results and discussion}

390 In this section the results from the calibration and validation of the developed model in

391 FG1 and FG2 units are shown and analysed. Observed and simulated values from April

3922009 to April 2012 are compared.

393

394

395

396

397

401

402

\subsection{Representation of the hydraulic operation}

Firstly, the hydraulic operation of both systems was simulated. Outlet flow from FG1 and FG2 was calculated by applying the water mass balance depicted in Eq. 12. The conservative variable conductivity was modelled and a satisfactory adjustment between observed and simulated data was obtained (Figure 3a). NSE presented a value of 0.85 in FG1 and 0.57 in FG2. The obtained hydraulic retention times (HRT) followed the same pattern in both units, reaching the highest values $(7.2 \mathrm{~d})$ during the first months of simulation (Figure 3b). Mean value of HRT was $1.0 \mathrm{~d}$ in FG1 and $1.3 \mathrm{~d}$ in FG2.

a)

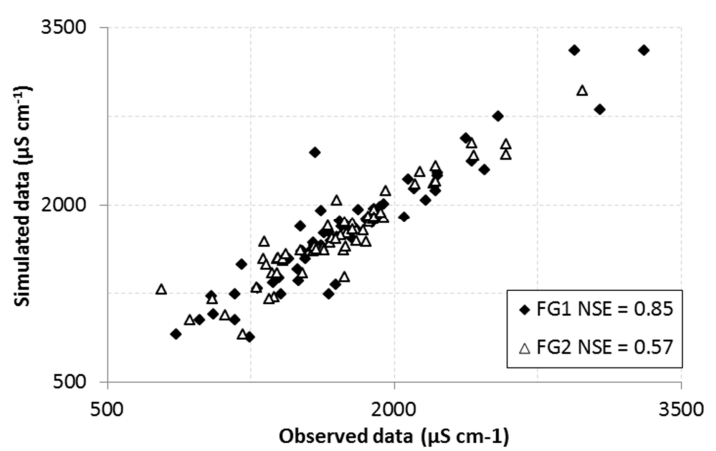

b)

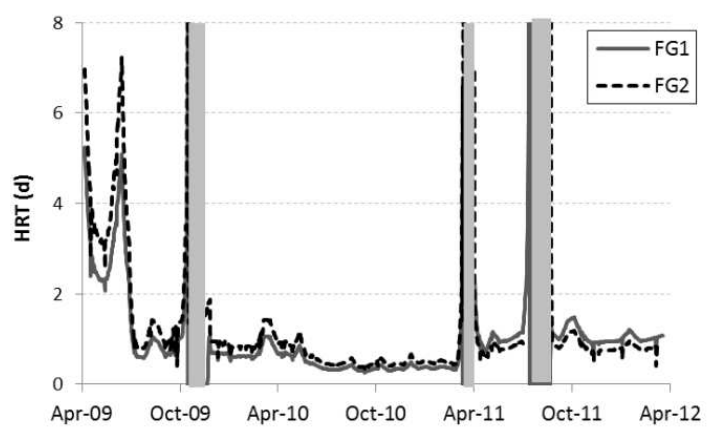

Figure 3. a) Comparison between observed and simulated conductivity values. b) Calculated hydraulic retention time (HRT, d). Grey vertical bars indicate dry periods.

\subsection{Calibration and validation results}

A set of parameter values that allow good fits between observed and simulated $X_{T S S}, X_{P}$ and TP outlet concentrations was achieved, although there is insufficient evidence to support that this is the only possible set. 
410 The first step was to calibrate $\alpha$ and $\beta$, which are parameters related to wind

411 resuspension. A power function (Figure 4a) was fitted to observed TSS values in FG1

412 unit, finding that $40 \mathrm{mg} \mathrm{L}^{-1}$ is the background concentration which is not related to wind

413 resuspension, $\alpha=6 \cdot 10^{-6}$ and $\beta=7.4$. When comparing these values with those obtained by

414 Cózar et al. (2005) $(\alpha=0.0405, \beta=2.58)$ it is observed that $\alpha$ is lower than that obtained

415 in their study and the calibrated value of $\beta$ is in the same order of magnitude.

a)

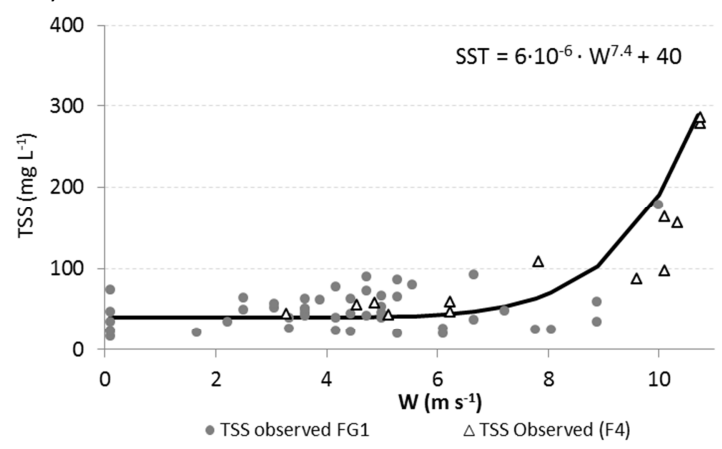

b)

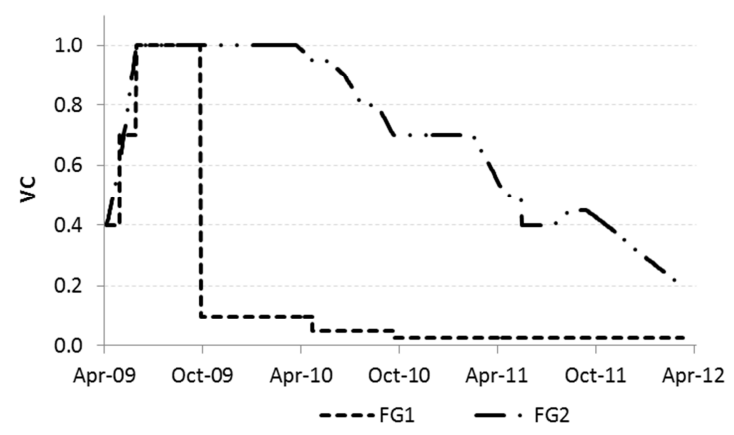

416

417

418

419

420

421

422

423

424

425

426

427

c)

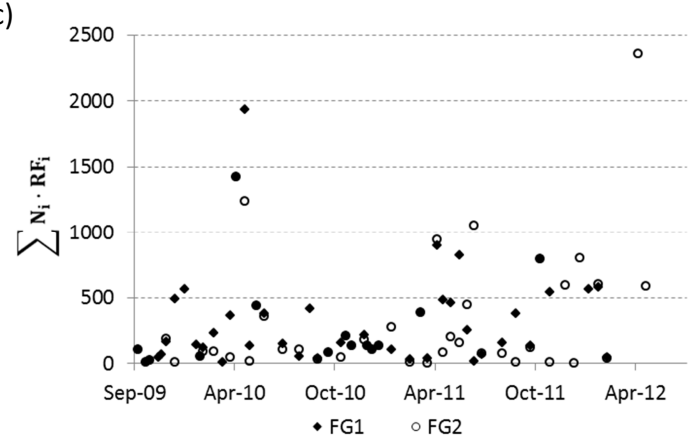

Figure 4. a) Correlation between maximum daily wind speed and TSS concentration in FG1, from April 2009 to April 2012. Circles represent outlet concentrations from FG1 and triangles from the adjacent CW F4 (see Figure 1). b) Emergent vegetation cover in FG1 and FG2. c) Sum of the number of birds $\left(\mathrm{N}_{\mathrm{i}}\right)$ multiplied by its resuspension factor $\left(\mathrm{RF}_{\mathrm{i}}\right)$ in FG1 and FG2.

Afterwards, values given to parameters $\mathrm{K}_{\mathrm{avi}}, \mathrm{K}_{\mathrm{veg} \mathrm{sed}}$ and $\mathrm{K}_{\mathrm{veg} \text { resus }}$ were chosen based on our previous experiences, since they were published for the first time in this model and bibliographic reference values are not available. The other parameters were initially used with the most common values found in bibliography and some of them needed to be modified in order to get the best fitting results (Table 5). Figure $4 \mathrm{c}$ shows that bird 
pressure in both FWSCW is lower in summer and winter and higher in spring, when surrounding fields are dried and birds move to Tancat de la Pipa for feeding, resting and reproduction.

$431 \mathrm{X}_{\mathrm{TSS}}$ content in $\mathrm{X}_{\mathrm{P}}$ was calculated using the values stated by Reynolds (2006) for different phytoplankton species in freshwater and the composition of the phytoplankton community in Tancat de la Pipa determined by Calero et al. (2015). A value of $14.6 \mathrm{mg}$ Chl $a \mathrm{~g} \mathrm{dw}^{-1}$ was calculated (i.e. $\mathrm{i}_{\mathrm{TSSXp}}=68.49 \mathrm{mg} \mathrm{dw} \mathrm{mg} \mathrm{Chl} a^{-1}$ ), which is in the middle of the range 3-39 $\mathrm{mg} \mathrm{Chl} a \mathrm{~g} \mathrm{dw}^{-1}$ determined by Reynolds (2006). Following Baretta-Bekker et al. (1997), $\mathrm{P}_{\max }$ was established to be double the value of $\mathrm{i}_{\mathrm{PXp}}$ while $\mathrm{P}_{\min }$ was half the value.

Regarding $\mathrm{i}_{\text {Psed }}$, the average concentration measured in laboratory analyses was $1.43 \cdot 10^{-}$ considered to be the average value of the measurements carried out by Martín (1998) in Lake Albufera sediments $\left(\mathrm{P}_{\text {sed }}=2.96 \mathrm{mg} \mathrm{P} \mathrm{L}^{-1}\right)$.

The fraction of particulate organic phosphorus was calculated as the fraction between particulate and total chemical oxygen demand. Calibration of dissolved and particulate fractions of inorganic phosphorus carried out in FG1 set the value of $K_{d}$ in $0.19 \mathrm{~L} \mathrm{mg}^{-1}$. However, this value could not be validated in the system FG2 because it generated simulated values lower than those observed and high values of RMSE. For these reasons, a different value of $\mathrm{K}_{\mathrm{d}}$ was used in FG2 $\left(0.07 \mathrm{~L} \mathrm{mg}^{-1}\right)$. This variation in partition coefficient for inorganic phosphorus could be due to differences in the adsorptive properties of the TSS in these systems. 
Table 5. Values of the parameters and stoichiometric coefficients.

\begin{tabular}{|c|c|c|c|}
\hline Parameter & Description & Value & Source \\
\hline $\mathrm{a}_{\mathrm{Xp}}$ & $\begin{array}{l}\text { Specific light attenuation coefficient of phytoplankton } \\
\left(\mathrm{L} \mathrm{mg}^{-1} \mathrm{~m}^{-1}\right) \text {. }\end{array}$ & 8.8 & Chapra, 1997 \\
\hline $\mathrm{D}_{0 \mathrm{P}}$ & $\begin{array}{l}\text { Diffusion coefficient of DIP } \\
\left(\mathrm{m}^{2} \mathrm{~d}^{-1}\right)\end{array}$ & $6.34 \cdot 10^{-5}$ & Reddy and DeLaune, 2008 \\
\hline $\mathrm{F}_{\mathrm{op}}$ & Fraction of $\mathrm{P}$ recycled to $\mathrm{OP}$ in $\mathrm{X}_{\mathrm{P}}$ decay. & 0.8 & Martin, 1998 \\
\hline $\mathrm{f}_{\mathrm{POP}}$ & Fraction of particulate organic phosphorus. & 0.34 & This study \\
\hline $\mathrm{F}_{\mathrm{pr}}$ & Fraction of resuspended $\mathrm{P}$ recycled to OP. & 0.5 & This study \\
\hline $\mathrm{G}_{\max }$ & Maximum growth rate for $\mathrm{X}_{\mathrm{P}}$ at $20^{\circ} \mathrm{C}\left(\mathrm{d}^{-1}\right)$. & 2 & Ambrose et al. 1988 \\
\hline $\mathrm{i}_{\mathrm{PXp}}$ & $\mathrm{P}$ content ratio in $\mathrm{X}_{\mathrm{P}}\left(\mathrm{mg} \mathrm{P} \mathrm{mg} \mathrm{Chl} a^{-1}\right)$. & 1.04 & This study \\
\hline $\mathrm{i}_{\mathrm{TSSXp}}$ & TSS content ratio in $\mathrm{X}_{\mathrm{P}}\left(\mathrm{mg} \mathrm{dw} \operatorname{mg~Chl} a^{-1}\right)$. & 68.49 & This study \\
\hline $\mathrm{I}_{\mathrm{s}}$ & Saturating light intensity for $\mathrm{X}_{\mathrm{P}}\left(1 \mathrm{y} \mathrm{d} \mathrm{d}^{-1}\right)$ & 150 & This study \\
\hline $\mathrm{K}_{\mathrm{avi}}$ & Coefficient of resuspension by avifauna $\left(\mathrm{mg} \mathrm{m}^{2} \mathrm{~L}^{-1} \mathrm{~d}^{-1}\right)$. & 1081 & This study \\
\hline $\mathrm{K}_{\mathrm{d}}$ & Partition coefficient for inorganic phosphorus $\left(\mathrm{L} \mathrm{mg}^{-1}\right)$. & $0.07-0.19$ & This study \\
\hline $\mathrm{k}_{\text {DIPup }}$ & $\begin{array}{l}\text { Saturation coefficient for DIP in } \mathrm{P} \text { uptake by } \mathrm{X}_{\mathrm{P}} \\
\left(\mathrm{mg} \mathrm{P} \mathrm{L}^{-1}\right) \text {. }\end{array}$ & 0.0005 & This study \\
\hline $\mathrm{K}_{\text {difu sed }}$ & $\begin{array}{l}\text { Coefficient of variation in the diffusion between water } \\
\text { and sediments. }\end{array}$ & 0.4 & This study \\
\hline $\mathrm{k}_{\mathrm{DO}}$ & $\begin{array}{l}\text { Saturation coefficient for DO in OP mineralization } \\
\left(\mathrm{mg} \mathrm{O}_{2} \mathrm{~L}^{-1}\right)\end{array}$ & 2.0 & This study \\
\hline $\mathrm{k}_{\mathrm{DO} \mathrm{Xp}}$ & $\begin{array}{l}\text { Saturation coefficient for } \mathrm{DO} \text { in } \mathrm{X}_{\mathrm{P}} \text { respiration } \\
\left(\mathrm{mg} \mathrm{O}_{2} \mathrm{~L}^{-1}\right) \text {. }\end{array}$ & 0.2 & Reichert et al., 2001 \\
\hline $\mathrm{K}_{\mathrm{e} 0}$ & Light attenuation coefficient of water $\left(\mathrm{m}^{-1}\right)$. & 0.1 & This study \\
\hline $\mathrm{K}_{\min \mathrm{OP}}$ & OP mineralization rate at $20^{\circ} \mathrm{C}\left(\mathrm{d}^{-1}\right)$ & 0.22 & Ambrose et al. 1988 \\
\hline $\mathrm{K}_{\mathrm{r}}$ & $\mathrm{X}_{\mathrm{P}}$ decay rate at $20^{\circ} \mathrm{C}\left(\mathrm{d}^{-1}\right)$ & 0.1 & Reichert et al., 2001 \\
\hline $\mathrm{K}_{\text {resp }}$ & $X_{P}$ respiration rate at $20^{\circ} \mathrm{C}\left(\mathrm{d}^{-1}\right)$ & 0.1 & Reichert et al., 2001 \\
\hline $\mathrm{K}_{\mathrm{veg} \text { resus }}$ & $\begin{array}{l}\text { Constant for trapping by emergent } \mathrm{VC} \text { in resuspension } \\
\text { processes. }\end{array}$ & 0.1 & This study \\
\hline $\mathrm{K}_{\mathrm{veg} \text { sed }}$ & $\begin{array}{l}\text { Constant for trapping by emergent } \mathrm{VC} \text { in sedimentation } \\
\text { processes. }\end{array}$ & 9.0 & This study \\
\hline$P_{\max }$ & Maximum $\mathrm{P}_{\text {int }}$ concentration (mg P mg Chl $\left.a^{-1}\right)$ & 2.08 & Baretta-Bekker et al. 1997 \\
\hline$P_{\text {max uptake }}$ & Maximum phosphorus uptake rate (mg P mg Chl $a^{-1} \mathrm{~d}^{-1}$ ). & 1.28 & Onandia et al., 2015 \\
\hline$P_{\min }$ & Minimum $\mathrm{P}_{\text {int }}$ concentration (mg P mg Chl $\left.a^{-1}\right)$. & 0.52 & Baretta-Bekker et al. 1997 \\
\hline $\mathrm{v}_{\mathrm{SOP}}$ & Sedimentation velocity of $\mathrm{OP}\left(\mathrm{m} \mathrm{d}^{-1}\right)$ & 0.07 & This study \\
\hline $\mathrm{v}_{\mathrm{sTIP}}$ & Sedimentation velocity of TIP $\left(\mathrm{m} \mathrm{d}^{-1}\right)$. & 0.04 & This study \\
\hline $\mathrm{v}_{\mathrm{SXTSS}}$ & Sedimentation velocity of $\mathrm{X}_{\mathrm{TSS}}\left(\mathrm{m} \mathrm{d}^{-1}\right)$. & 0.07 & This study \\
\hline $\mathrm{v}_{\mathrm{s} X \mathrm{p}}$ & Sedimentation velocity of $\mathrm{X}_{\mathrm{P}}\left(\mathrm{m} \mathrm{d}^{-1}\right)$. & 0.07 & This study \\
\hline$\alpha$ & First coefficient of resuspension by wind. & $6 \cdot 10^{-6}$ & This study \\
\hline$\beta$ & Second coefficient of resuspension by wind. & 7.4 & This study \\
\hline$\theta_{\text {difu }}$ & Temperature coefficient for DIP diffusion. & 1.0234 & Reddy and DeLaune, 2008 \\
\hline$\theta_{\mathrm{G}}$ & Temperature coefficient for $X_{P}$ growth. & 1.068 & Ambrose et al. 1988 \\
\hline$\theta_{\min \mathrm{OP}}$ & Temperature coefficient for mineralization of OP. & 1.08 & Ambrose et al. 1988 \\
\hline$\theta_{\mathrm{r}}$ & Temperature coefficient for $X_{P}$ decay. & 1.02 & Ambrose et al. 1988 \\
\hline$\theta_{\text {resp }}$ & Temperature coefficient for $X_{P}$ respiration. & 1.045 & Ambrose et al. 1988 \\
\hline
\end{tabular}


Figures 5, 6 and 7 show the relationships between observed and simulated data for $\mathrm{X}_{\mathrm{TSS}}$,

$456 \mathrm{X}_{\mathrm{P}}$ and TP in FG1 (calibration) and FG2 (validation). Calibration results were

457 satisfactory for the three water quality variables. Furthermore, validation in FG2 shows

458 even better adjustment, which confers greater robustness to the model.

459 Lower TSS concentrations fit slightly better than higher ones, especially in FG1 where 460 outlet concentrations above $100 \mathrm{mg} \mathrm{L}^{-1}$ were observed. Even so, a good adjustment was 461 obtained when comparing with TSS concentration.

462

463

464

465

466

467

468

469

470

471

472

473

474

475

476 a) 200

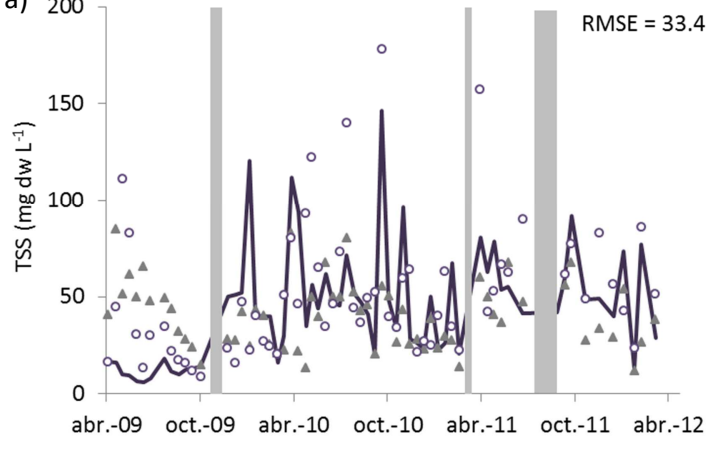

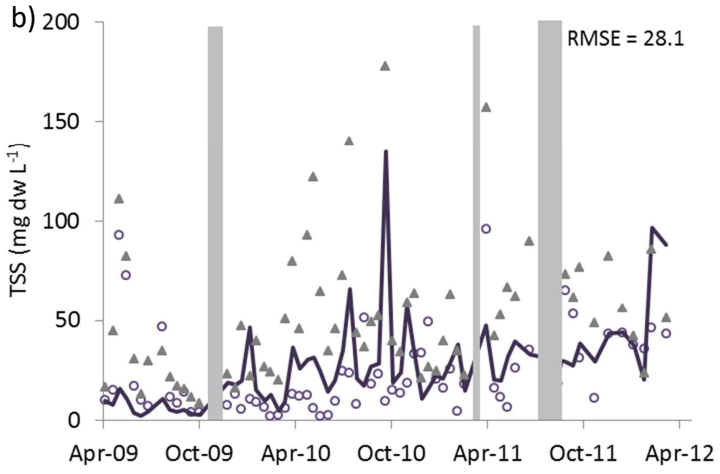

Figure 5. Comparison between observed (circles) and simulated (line) $\mathrm{X}_{\mathrm{TSS}}$ outlet concentrations ( $\mathrm{mg} \mathrm{dw} \mathrm{L}^{-1}$ ) in (a) FG1 and (b) FG2. Triangles represent observed inlet concentrations and grey vertical bars indicate dry periods.

In relation to $\mathrm{X}_{\mathrm{TSS}}$ removal, the FG1 FWSCW showed a change in its performance during the studied period since TSS removal was only achieved during the first year of operation and from then on, outlet concentrations were higher than inlet ones (Figure 5a). The model is able to successfully reproduce both trends and good adjustment is achieved during the entire studied period. The change in TSS efficiency removal that took place in FG1 from March 2010 onwards is associated with a drop in emergent vegetation cover (Figure 4b), since it was harvested in October 2009 and it did not grow again. It was proved that emergent vegetation cover is statistically related with observed TSS concentrations $(\mathrm{p}<0.01)$. 

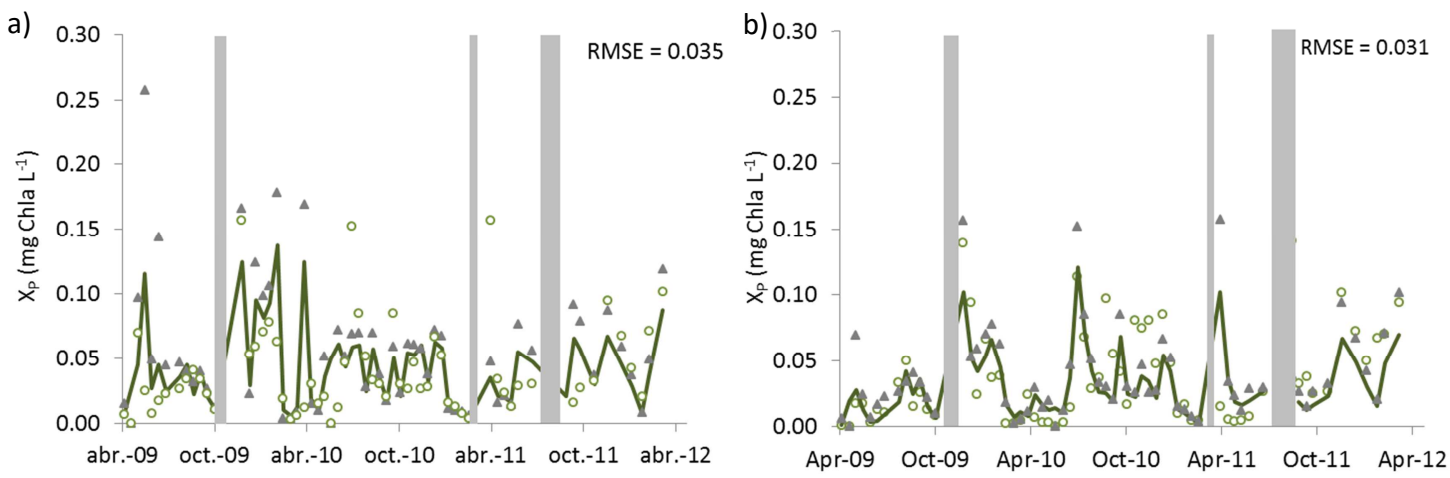

Figure 6. Comparison between observed (circles) and simulated (line) $\mathrm{X}_{\mathrm{P}}$ outlet concentrations (mg Chl $a \mathrm{~L}^{-1}$ ) in (a) FG1 and (b) FG2. Triangles represent observed inlet concentrations and grey vertical bars indicate dry periods.
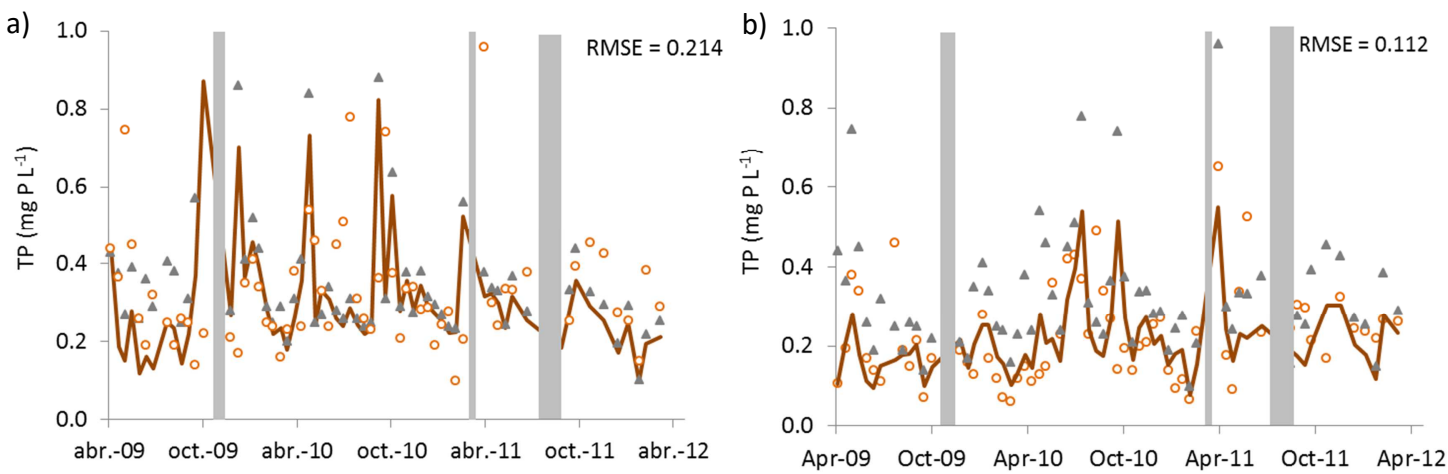

Figure 7. Comparison between observed (circles) and simulated (line) TP outlet concentrations (mg P L ${ }^{-1}$ ) in (a) FG1 and (b) FG2. Triangles represent observed inlet concentrations and grey vertical bars indicate dry periods.

Regarding phytoplankton and total phosphorus results (Figures 6 and 7), the model properly simulates outlet concentrations in both systems.

Some simulations that did not include vegetation cover were carried out in order to clarify its significance in $\mathrm{X}_{\text {TSS }}$ performance. Figure 8 shows that the higher the vegetation cover, the lower the concentrations achieved. Furthermore, the developed 492 model revealed that the magnitude of the effect of emergent vegetation in trapping particulate matter is much greater in sedimentation processes $\left(K_{\mathrm{veg} \text { sed }}=9.0\right)$ than in resuspension ones $\left(\mathrm{K}_{\mathrm{veg} \text { resus }}=0.1\right)$. 
a)

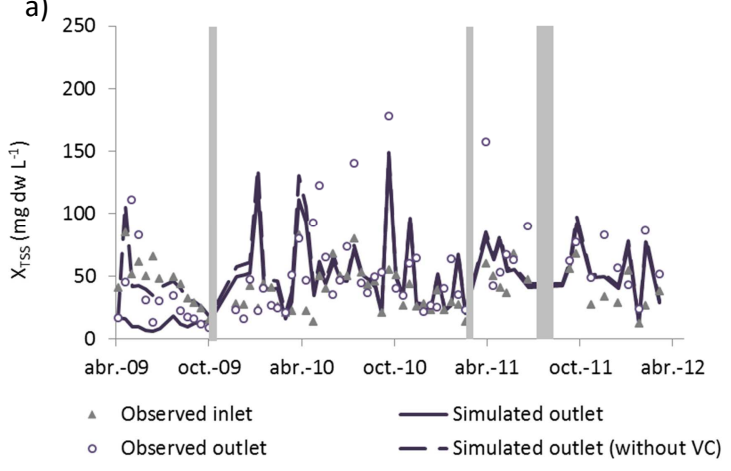

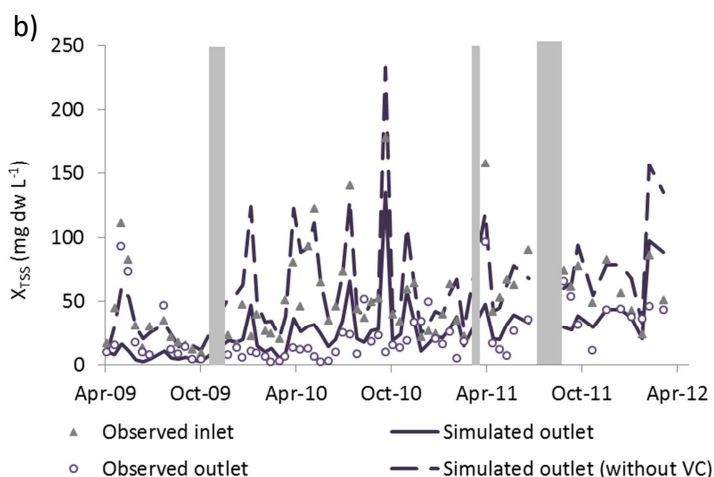

495

496

497

498

499

500

501

502

503

504

505

506

507

$508 \mathrm{X}_{\text {TSS }}$ was the most susceptible component to changes in the value of the parameters,
Figure 8. Simulated TSS concentrations with plant effects (solid line) and without plant effects (dotted line) in (a) FG1 and (b) FG2.

\subsection{Sensitivity results}

The sensitivity analysis was carried out in order to find out the influence of the parameter values over components concentrations. Table 6 depicts a classification of the most sensitive parameters for each component based on the mean absolute-relative sensitivity calculated.

Table 6. Parameter classification based on the mean absolute-relative sensitivity function in AQUASIM.

\begin{tabular}{|c|c|c|c|c|c|}
\hline & $\mathrm{X}_{\mathrm{TSS}}$ & $X_{P}$ & PIT & $\mathrm{P}_{\text {int }}$ & $\mathrm{OP}$ \\
\hline$>1$ & $\begin{array}{l}\mathrm{K}_{\text {veg sed }}, \mathrm{V}_{\mathrm{sTSS}}, \\
\mathrm{K}_{\text {avi }}\end{array}$ & & & & \\
\hline$>0.1-0.5<$ & $\begin{array}{l}\mathrm{i}_{\mathrm{TSSXp}}, \mathrm{v}_{\mathrm{sXp}}, \\
\mathrm{K}_{\text {veg resus }}, \theta_{\text {resp }}, \\
\theta_{\mathrm{r}}\end{array}$ & & & $\begin{array}{l}\mathrm{P}_{\max }, \theta_{\mathrm{r}}, \\
\mathrm{P}_{\max \text { uptake }}, \\
\mathrm{P}_{\min }\end{array}$ & \\
\hline$<0.1$ & $\mathrm{G}_{\max }, \mathrm{K}_{\mathrm{r}}$ & $\begin{array}{l}\theta_{\text {resp }}, \theta_{\mathrm{r}}, \\
\mathrm{v}_{\mathrm{sXp}}, \mathrm{K}_{\mathrm{r}}, \\
\mathrm{K}_{\text {resp }}, \theta_{\mathrm{G}}, \\
\mathrm{K}_{\text {avi }}, \mathrm{I}_{\mathrm{S}}, \mathrm{f}, \\
\mathrm{G}_{\max }\end{array}$ & $\begin{array}{l}\mathrm{K}_{\text {veg sed }}, \\
\mathrm{V}_{\mathrm{sPIP}}, \mathrm{K}_{\mathrm{d}}, \\
\mathrm{K}_{\text {avi }}\end{array}$ & $\begin{array}{l}\mathrm{K}_{\mathrm{avi}}, \theta_{\mathrm{G}}, \mathrm{K}_{\mathrm{r}}, \\
\mathrm{I}_{\mathrm{S}}, \mathrm{i}_{\mathrm{PXp}}, \theta_{\text {resp }}, \\
\mathrm{G}_{\max }, \mathrm{f}\end{array}$ & $\begin{array}{l}f_{\mathrm{POP}}, \mathrm{K}_{\mathrm{veg} \mathrm{sed}}, \\
\theta_{\min \mathrm{OP}}, \mathrm{v}_{\mathrm{sOP}}\end{array}$ \\
\hline
\end{tabular}
particularly in relation to $\mathrm{K}_{\mathrm{veg} \text { sed }}$, $\mathrm{v}_{\mathrm{sTSS}}$ and $\mathrm{K}_{\mathrm{avi}}$. $\mathrm{i}_{\mathrm{TSSX}}, \mathrm{v}_{\mathrm{sXp}}, \mathrm{K}_{\mathrm{veg}}$ resus, $\theta_{\text {resp }}$ and $\theta_{\mathrm{r}}$ presented intermediate sensitivity for $\mathrm{X}_{\mathrm{TSS}}$, meanwhile parameters related to internal 
511 accumulation of phosphorus and temperature coefficient for $X_{P}$ decay were the most

512 sensitive parameters for $\mathrm{P}_{\text {int }}$. $\mathrm{X}_{\mathrm{P}}$, PIT and OP showed the lowest absolute-relative 513 sensitivity values, and among the parameters that most affect these components are their

514 sedimentation velocities, the coefficient for trapping by emergent VC in sedimentation 515 processes, the temperature coefficient for $X_{P}$ respiration and the fraction of particulate 516 organic phosphorus.

\subsection{Mass budgets}

519 Few studies offer information about the relative significance of the different processes 520 for efficient removal in FWSCWs (Wang and Mitsch, 2000). However, this is a key 521 issue for making decisions by $\mathrm{CW}$ managers and this type of mechanistic models pave the way for further contributions in this area. $X_{T S S}, X_{P}$ and TP budgets were calculated from simulation results in FG1 and FG2 from April 2009 to April 2012. $\mathrm{X}_{\mathrm{TSS}}$ associated to inflow represents no more than $60 \%$ of the total amount of solids that enters the studied FWSCWs (Figure 9). Inputs produced by resuspension processes caused by wind and by avifauna means $50 \%$ of TSS entering to FG1 and 44\% in FG2, with a predominant importance of wind resuspension in both budgets. In FG1 and FG2 FWSCWs sedimentation is the most influential process in $\mathrm{X}_{\mathrm{TSS}}$ performance, which is consistent with observations made by Schmid et al. (2005), especially in FG2 where $\mathrm{X}_{\mathrm{TSS}}$ sedimentation removes $75 \%$ of solids that comes into the system. The greater importance of sedimentation in FG2 is associated with the higher emergent vegetation cover in this system. Likewise, higher vegetation cover in FG2 explains that resuspension processes are lower in this system. 
534 Processes related to phytoplankton are of little importance in the $\mathrm{X}_{\text {TSS }}$ budget.

535 Phytoplankton dynamic affects turbidity but its contribution to $\mathrm{X}_{\text {TSS }}$ concentration is 536 very low (2\%, approximately).

537

538

539

540

541

542

543 Regarding the phytoplankton budget, sedimentation is the most important process

Figure 9. Total suspended solids budget (kg) for (a) FG1 and (b) FG2 as calculated from the model for April 2009-2012. Grey-coloured shapes represent inputs to the system and white-coloured shapes are outputs. a)

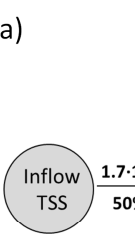
although it is much lower than in $\mathrm{X}_{\mathrm{TSS}}$ balance (Figure 10). The contribution of the growth process is very low.

a)

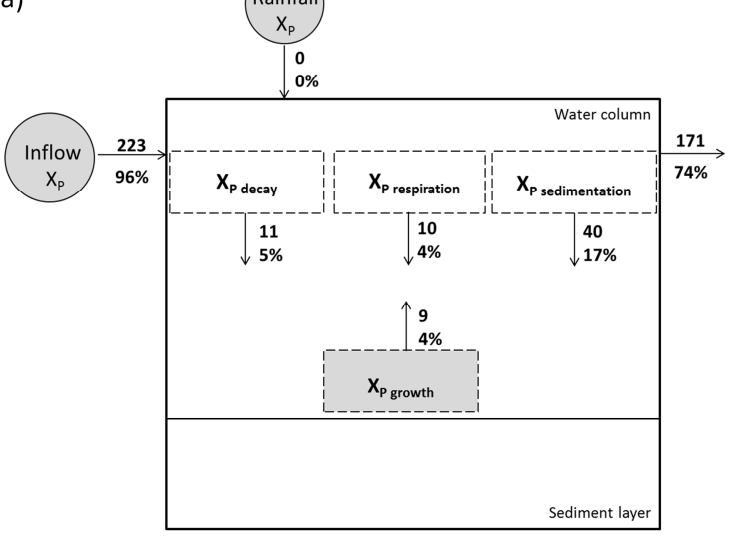

b)

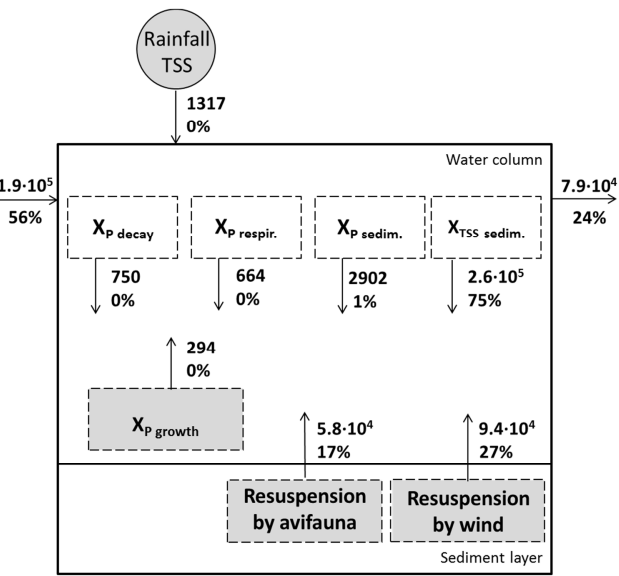


551 Sedimentation of the different particulate components including phytoplankton is the 552 most important process in TP budget, with OP sedimentation being the most important 553 one. Diffusion from sediment and resuspension processes have little influence in TP 554 budget (Figure 11). The different influence of resuspension in $\mathrm{TP}$ and $\mathrm{X}_{\mathrm{TSS}}$ budgets is a 555 consequence of the low average phosphorus content measured in sediment $\left(i_{\text {Psed }}=0.143\right.$ $556 \mathrm{mg} \mathrm{P} \mathrm{g} \mathrm{dw}^{-1}$ ) when compared to the range between $0.147-4.088 \mathrm{mg} \mathrm{g}^{-1}$ cited in 557 bibliography (Kadlec and Wallace, 2009).

558 The amount of $\mathrm{X}_{\mathrm{TSS}}$ and TP associated to rainfall can be considered negligible, as they represent less than $1 \%$ of the total inputs to the systems.

561 a)

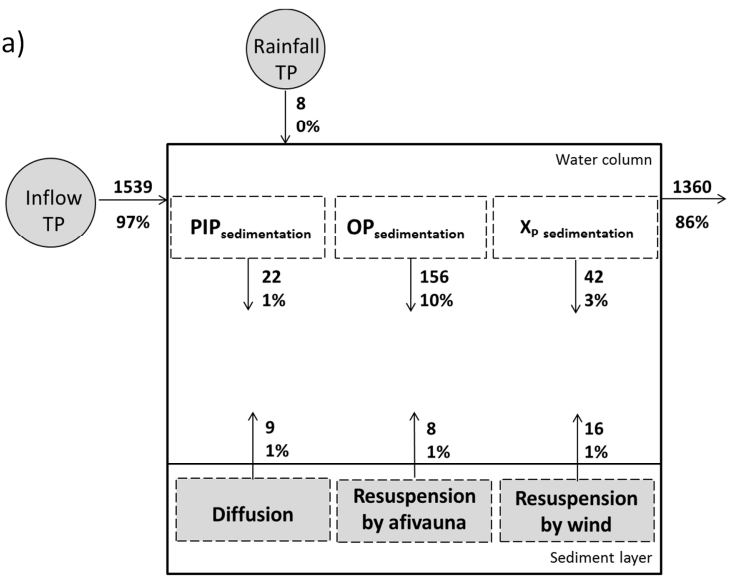

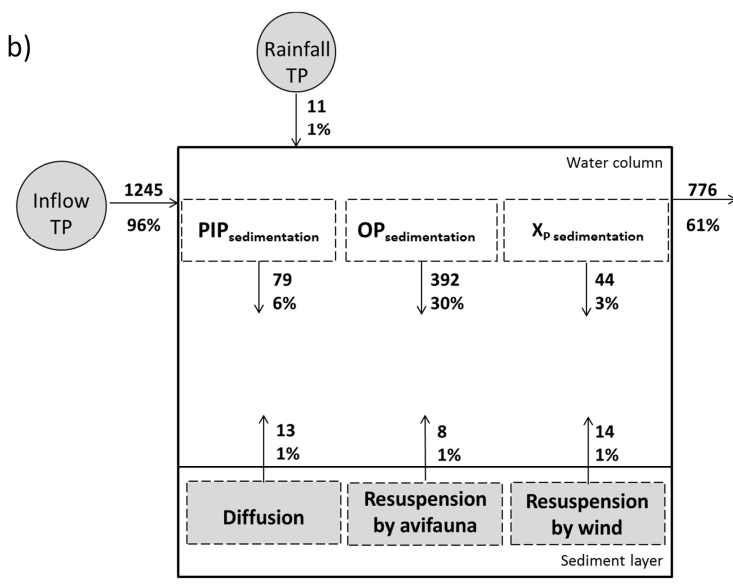

b) Sediment layer

Figure 11. Total phosphorus budget (kg) for (a) FG1 and (b) FG2 as calculated from the model for April 2009-2012. Grey-coloured shapes represent inputs to the system and white-coloured shapes are outputs.

\section{Conclusions}

567 In this paper a new model has been described to simulate the concentrations of TSS,

568 linked to phytoplankton and TP in free water surface CWs. In order to achieve this aim,

569 the main processes involved have been modelled by developing kinetic equations. The

570 software AQUASIM has been used to implement these model equations together with

571 water flow. The model has been calibrated and validated comparing simulated and 
572 observed outlet concentrations obtained in two full-scale FWSCWs named as FG1 and 573 FG2, from April 2009 to April 2012. A sensitivity analysis has been carried out in order 574 to clarify which are the most influential parameters.

575 The results reveal that the model suitably represents the concentrations of TSS, 576 phytoplankton and TP. An outstanding innovation of this model is the link between 577 phytoplankton and TSS, enabling researchers to quantify the contribution of 578 phytoplankton to the TSS performance. Furthermore, the model distinguishes 579 resuspension into that produced by wind and by avifauna activity respectively, and 580 demonstrates that these are crucial processes to be included when modelling these 581 components.

582 One of the most remarkable contributions of this paper is to model the effect of emergent vegetation cover in TSS, phytoplankton and TP performances and proves its crucial role in improving TSS sedimentation and preventing resuspension.

This model fills an existing gap in the development of mechanistic models in FWSCWs and enhances the knowledge about the processes that take place. Besides being able to implement future scenarios, the model is a useful support tool for designing and making decisions.

\section{Acknowledgements}

591 We would like to strongly thank to Pablo Vera (SEO/BirdLife) for him collaboration

592 with waterfowl monitoring and data analysis and to Maria Antonia Rodrigo and Matilde 593 Segura (ICBiBE, Universitat de València) for collecting Chl $a$ data. We would also like acknowledge the support of Confederación Hidrográfica de Júcar (CHJ, MMARM) and the staff members in Tancat de la Pipa. 


\begin{tabular}{|c|c|c|}
\hline Parameter & Description & Units \\
\hline$a_{X p}$ & Specific light attenuation coefficient of phytoplankton & $\mathrm{L} \mathrm{mg}^{-1} \mathrm{~m}^{-1}$ \\
\hline $\mathrm{C}_{\mathrm{et}, \mathrm{n}}$ & Concentration in the evapotranspiration of the component & $\mathrm{mg} \mathrm{L}^{-1}$ \\
\hline & $n$. & \\
\hline $\mathrm{C}_{\mathrm{gr}, \mathrm{n}}$ & Concentration in the percolation flow of the component $n$. & $\mathrm{mg} \mathrm{L}^{-1}$ \\
\hline $\mathrm{C}_{\mathrm{in}, \mathrm{n}}$ & Inlet concentration of the component $n$. & $\operatorname{mg~L}{ }^{-1}$ \\
\hline $\mathrm{C}_{\mathrm{n}}$ & Outlet concentration of the component $n$. & $\operatorname{mg~L}{ }^{-1}$ \\
\hline $\mathrm{C}_{\mathrm{rf}, \mathrm{n}}$ & Concentration in the rainfall of the component $n$. & $\operatorname{mg~L}{ }^{-1}$ \\
\hline $\mathrm{D}_{0 \mathrm{P}}$ & Diffusion coefficient of DIP. & $m^{2} d^{-1}$ \\
\hline DIP & Dissolved inorganic phosphorus. & \\
\hline DO & Dissolved oxygen. & $\mathrm{mg} \mathrm{O}_{2} \mathrm{~L}^{-1}$ \\
\hline $\mathrm{dw}$ & Dry weight. & \\
\hline $\mathrm{F}$ & Fetch. & $\mathrm{m}$ \\
\hline $\mathrm{f}$ & Photoperiod, the fraction of daylight. & \\
\hline$f_{d}$ & Dissolved fraction of the inorganic phosphorus. & \\
\hline$f_{\mathrm{POP}}$ & Fraction of particulate organic phosphorus. & \\
\hline $\mathrm{F}_{\mathrm{op}}$ & Fraction of $\mathrm{P}$ recycled to $\mathrm{OP}$ in $\mathrm{X}_{\mathrm{P}}$ decay. & \\
\hline $\mathrm{F}_{\mathrm{pr}}$ & Fraction of resuspended $\mathrm{P}$ recycled to OP. & \\
\hline $\mathrm{G}_{\mathrm{L}}$ & Light limitation in phytoplankton growth kinetics. & \\
\hline $\mathrm{G}_{\max }$ & Maximum growth rate for $\mathrm{X}_{\mathrm{P}}$ at $20^{\circ} \mathrm{C}$. & $d^{-1}$ \\
\hline $\mathrm{H}$ & Water depth. & $\mathrm{m}$ \\
\hline $\mathrm{I}_{0}$ & Average incident daylight intensity. & ly d $\mathrm{d}^{-1}$ \\
\hline $\mathrm{i}_{\text {Psed }}$ & $\mathrm{P}$ content in the sediments. & mg P mg d.w. \\
\hline
\end{tabular}


$\mathrm{i}_{\mathrm{PXp}} \quad \mathrm{P}$ content in phytoplankton tissues.

mg P mg Chla

$i_{\text {TSSXp }} \quad$ TSS content ratio in $X_{P}$.

mg dw mg

Chla $^{-1}$

$\mathrm{I}_{\mathrm{S}} \quad$ Saturating light intensity for $\mathrm{X}_{\mathrm{P}}$.

ly $\mathrm{d}^{-1}$

$\mathrm{K}_{20} \quad$ Process rate at $20^{\circ} \mathrm{C}$.

$\mathrm{d}^{-1}$

$\mathrm{K}_{\mathrm{avi}} \quad$ Coefficient of resuspension by avifauna.

$m g m^{2} L^{-1} d^{-1}$

$\mathrm{K}_{\mathrm{d}} \quad$ Partition coefficient for inorganic phosphorus.

$\mathrm{L} \mathrm{mg}^{-1}$

$\mathrm{K}_{\text {difu sed }} \quad$ Coefficient of variation in the diffusion between water and sediments.

$\mathrm{k}_{\text {DIPup }} \quad$ Saturation coefficient for DIP in $\mathrm{P}$ uptake by $\mathrm{X}_{\mathrm{P}}$.

$\operatorname{mg~P~L}{ }^{-1}$

$\mathrm{k}_{\mathrm{DO}} \quad$ Saturation coefficient for DO in OP mineralization.

$\mathrm{mg} \mathrm{O}_{2} \mathrm{~L}^{-1}$

$\mathrm{k}_{\mathrm{DO} X \mathrm{Xp}} \quad$ Saturation coefficient for DO in $\mathrm{X}_{\mathrm{P}}$ respiration.

$\mathrm{mg} \mathrm{O}_{2} \mathrm{~L}^{-1}$

$\mathrm{K}_{\mathrm{e}} \quad$ Extinction coefficient.

$\mathrm{m}^{-1}$

$\mathrm{K}_{\mathrm{e} 0} \quad$ Light attenuation coefficient of water.

$\mathrm{m}^{-1}$

$\mathrm{K}_{\min \mathrm{OP}}$

OP mineralization rate at $20^{\circ} \mathrm{C}$.

$\mathrm{d}^{-1}$

$\mathrm{K}_{\mathrm{r}} \quad \mathrm{X}_{\mathrm{P}}$ decay rate at $20^{\circ} \mathrm{C}$.

$\mathrm{d}^{-1}$

$\mathrm{K}_{\text {resp }} \quad \mathrm{X}_{\mathrm{P}}$ respiration rate at $20^{\circ} \mathrm{C}$.

$d^{-1}$

$\mathrm{K}_{\mathrm{T}}$

Process rate at temperature $\mathrm{T}$.

$\mathrm{d}^{-1}$

$\mathrm{K}_{\mathrm{veg} \text { resus }} \quad$ Coefficient for trapping by emergent $\mathrm{VC}$ in resuspension processes.

$\mathrm{K}_{\text {veg sed }} \quad$ Coefficient for trapping by emergent $\mathrm{VC}$ in sedimentation processes.

L Wavelength.

$\mathrm{m}$

NSE Nash-Sutcliffe efficiency. 
$\mathrm{OP}_{\text {res }} \quad$ OP enterning to the system by wind resuspension. $\mathrm{mg} \mathrm{P} \mathrm{L}^{-1}$

PIP Particulate inorganic phosphorus.

$\mathrm{PIP}_{\text {res }} \quad$ PIP enterning to the system by wind resuspension. $\mathrm{mg} \mathrm{P} \mathrm{L}^{-1}$

$\mathrm{P}_{\max } \quad$ Maximum $\mathrm{P}_{\text {int }}$ rate for $\mathrm{X}_{\mathrm{P}} . \quad \mathrm{mg} \mathrm{P} \mathrm{mg} \mathrm{Chla}$

$\mathrm{P}_{\max \text { uptake }} \quad$ Maximum phosphorus uptake rate. $\quad \mathrm{mg} \mathrm{P} \mathrm{mg} \mathrm{Chla}{ }^{-}$

${ }^{1} \mathrm{~d}^{-1}$

$\mathrm{P}_{\min } \quad$ Minimum $\mathrm{P}_{\text {int }}$ rate for $\mathrm{X}_{\mathrm{P}} . \quad \mathrm{mg} \mathrm{P} \mathrm{mg} \mathrm{Chla}$

$\mathrm{P}_{\text {sed }} \quad$ Phosphorus concentration in interstitial water in sediments.

Qet Evapotranspiration flow. $\quad \mathrm{L} \mathrm{s}^{-1}$

Q $\quad$ Gains/losses of the system by percolation to groundwater. $\mathrm{L} \mathrm{s}^{-1}$

Q in Inlet flow. $\quad \mathrm{L} \mathrm{s}^{-1}$

Qout Outlet flow. $\quad \mathrm{L} \mathrm{s}^{-1}$

Q Direct rainfall flow entering to the system. $\mathrm{L} \mathrm{s}^{-1}$

$\mathrm{RF}_{\mathrm{i}} \quad$ Resuspension factor of the group of birds $i$.

RMSE Root mean square error.

$\mathrm{r}_{\mathrm{j}} \quad$ Reaction rate for process $j . \quad \mathrm{d}^{-1}$

$\mathrm{r}_{\mathrm{n}} \quad$ Reaction rate for the component $n . \quad \mathrm{d}^{-1}$

t Time. $\quad$ s

T Temperature. $\quad{ }^{\circ} \mathrm{C}$

TCOD Total chemical oxygen demand. $\quad \mathrm{mg} \mathrm{O}_{2} \mathrm{~L}^{-1}$

TSS Total suspended solids.

$\mathrm{X}_{\text {TSS res }} \quad$ TSS enterning to the system by wind resuspension. $\mathrm{mg} \mathrm{L}^{-1}$

V Water volume. $\quad$ L 
VC Vegetation cover, the fraction of the CW surface covered by vegetation.

\begin{tabular}{|c|c|}
\hline $\mathrm{V}_{\mathrm{SOP}}$ & Sedimentation velocity of OP. \\
\hline $\mathrm{V}_{\mathrm{sTIP}}$ & Sedimentation velocity of TIP. \\
\hline $\mathrm{V}_{\text {sTSS }}$ & Sedimentation velocity of TSS. \\
\hline $\mathrm{v}_{\mathrm{sXp}}$ & Sedimentation velocity of $X_{p}$. \\
\hline $\mathrm{W}$ & Maximum daily wind speed. \\
\hline $\mathrm{W}_{0}$ & Minimum wind speed to cause resuspension. \\
\hline$\alpha$ & First coefficient of resuspension by wind. \\
\hline$\beta$ & Second coefficient of resuspension by wind. \\
\hline$\theta$ & Temperature coefficient. \\
\hline$\theta_{\text {difu }}$ & Temperature coefficient for DIP diffusion. \\
\hline$\theta_{\mathrm{G}}$ & Temperature coefficient for $\mathrm{X}_{\mathrm{P}}$ growth. \\
\hline$\theta_{\min } \mathrm{OP}$ & Temperature coefficient for mineralization of OP. \\
\hline$\theta_{\mathrm{r}}$ & Temperature coefficient for $\mathrm{X}_{\mathrm{P}}$ decay. \\
\hline$\theta_{\text {resp }}$ & Temperature coefficient for $\mathrm{X}_{\mathrm{P}}$ respiration. \\
\hline$v_{n, j}$ & Stoichiometric factor for component $n$ and process $j$. \\
\hline$\delta(\mathrm{W}, \mathrm{W} 0)$ & Step function that determines the periods when the wind- \\
\hline
\end{tabular}

600 Bibliography

601- Ambrose, Jr., R.B., Martin, J. L. and Wool, T.A., 1988. WASP4, A Hydrodynamic and

602 Water Quality Model -- Model Theory, User's Manual and Programmer's Guide.

603 USEPA, Athens, GA. 
604 APHA, 1991. Standard Methods for the Examination of Water and Wastewater, 17th ed. American Publish Health Association, Washington, DC, USA. Ballatore, T.J., Muhandiki, V.S., 2002. The case for a World Lake Vision. Hydrol.

607 Process. 16, 2079-2089. Baretta-Bekker, J.G., Baretta, J.W., Ebenhoh, W., 1997. Microbial Dynamics in the Marine Ecosystem Model \{ERSEM\} $\{$ II $\}$ with Decoupled Carbon Assimilation and 610 Nutrient Uptake. Journal of Sea Research 38(3-4):195-211.

611 Calero, S., Segura, M., Rojo, C., Rodrigo, M.A., 2015. Shifts in plankton assemblages 612 promoted by free water surface constructed wetlands and their implications in 613 eutrophication remediation. Ecol. Eng., 74, 385-393.

614 Chapra, St. C., 1997. Surface Water-Quality Modeling. McGraw-Hill.

615 Chavan, P.V., Dennett, K.E., 2008. Wetland simulation model for nitrogen, phosphorus, 616 and sediments retention in constructed wetlands. Water Air Soil Pollut. 187, 109-118.

617 Comín, F. A., Herrera-Silveira, J. A., Martín M., 1997. Flamingo footsteps enhance 618 nutrient release from the sediment to the water column. Wetlands International 619 Publication. 43:211-227.

620 Coveney, M.F., Stites, D.L., Lowe, E.F., Battoe, L.E., Conrow, R., 2002. Nutrient 621 removal from eutrophic lake water by wetland filtration. Ecol. Eng. 19, 141-159.

622 Cózar A., Galvez, J.A., Hull V., García, C.M., Loiselle, S.A., 2005. Sediment 623 resuspension by wind in a shallow lake of Esteros del Ibera (Argentina): a model based 624 on turbidimetry. Ecol Model, 186: 63-76.

625 Di Toro D.M., O’Connor D.J., Thomann R.V., 1971. A dynamic model of the 626 phytoplankton population in the Sacramento-San Joaquin delta. Adv. Chem. Ser., 106, 627 131-180 (1971). 
628 Douglas, R.W., Rippey, B., 2000. The random redistribution of sediment by wind in a

629 lake. Limnol. Oceanogr. 45 (3), 686-694.

630 Giraldi, D., de Michieli Vitturi, M., Iannelli, R., 2010. FITOVERT: A dynamic 631 numerical model of subsurface vertical flow constructed wetlands. Environ. Modell. 632 Softw. 25, 633-640.

633 Glassom, D., Branch G.M., 1997. Impact of predation by greater flamingos 634 Phoenicopterus ruber on the macrofauna of two southern African lagoons, Mar. Ecol. 635 Prog. Ser. 150, 1-12.

636 Greenway, M., 2010. Wetlands and ponds for stormwater treatment in subtropical 637 Australia: their effectiveness in enhancing biodiversity and improving water quality? J. 638 Contemp. Water. Res. Edu. 146, 22-38.

639 Harter, S.K., Mitsch, W.J., 2003. Patterns of short-term sedimentation in a freshwater 640 created marsh. J. Environ. Qual. 32, 325-334.

641 Henze, M., Gujer, W., Mino, T., van Loosdrecht, M.C.M., 2000. Activated sludge 642 models ASM1, ASM2, ASM2D and ASM3. IWA Scientific and Technical Report No.9, 643 IWA Publishing, London, UK.

644 Hosokawa Y., Horie T., 1992. Flow and particulate nutrient removal by wetland with 645 emergent macrophyte. Sci. Total Environ. 1271-1282.

646 ISO 11263:1994. Soil quality. Determination of phosphorus. Spectrometric 647 determination of phosphorus soluble in sodium hydrogen carbonate solution.

648 Jeffrey, S.W., Humphrey, G.P., 1975. New spectrophotometric equations for 649 determining chlorophylls a, b, c1 and c2 in higher plants, algae and natural 650 phytoplankton. Biochem. Physiol. Pflanzen. 19, 191-194.

651 Kadlec, R.H., Knight, R.L., 1996. Treatment Wetlands. CRC Press, Boca Raton, FL 893 652 pp. 
653 Kadlec, R.H., 1997. An autobiotic wetland phosphorus model. Ecol. Eng., 8(2), 145654172.

655 Kadlec, R.H., Wallace, S.D., 2009. Treatment Wetlands, Second Ed. CRC Press, Boca 656 Raton, FL.

657 Langergraber, G., 2001. Development of a simulation tool for subsurface flow 658 constructed wetlands. Ph.D. thesis. Wiener Mitteilungen 169, Vienna, Austria.

659 Langergraber, G., Rousseau, D., García, J., Mena, J., 2009. CWM1 - A general model to 660 describe biokinetic processes in subsurface flow constructed wetlands. Water Sci. 661 Technol. 59, 1687-1697.

662 Langergraber, G., Šimůnek, J., 2012. Reactive Transport Modeling of Subsurface Flow 663 Constructed Wetlands Using the HYDRUS Wetland Module. Vadose Zone Journal, $66411(2)$.

665 Martín, M., 1998. Modelación de la Calidad en Aguas Superficiales. Aplicación al caso 666 de la Albufera de Valencia. Ph.D. thesis. University of Valencia. Spain.

667 Martín, M., Oliver, N., Hernández-Crespo, C., Gargallo, S.,Regidor, M.C., 2013. The 668 use of free water surface constructed wetland to treat the eutrophicated waters of lake 669 L'Albufera de Valencia (Spain). Ecol. Eng. 50, 52-61.

670 Mburu, N., Sanchez-Ramos, D., Rousseau, D.P.L., van Bruggen, J.J.A., Thumbi, G., 671 Stein, O.R., Hook, P.B., Lens, P.N.L., 2012. Simulation of carbon, nitrogen and sulphur 672 conversion in batch-operated experimental wetland mesocosms. Ecol. Eng. 42, 304673315.

674 Meyer, D., Chazarenc, F., Claveau-Mallet, D., Dittmer, U., Forquet, N., Molle, P., 675 Morvannou, A., Pálfy, T., Petitjean, A., Rizzo, A., Samsó, R., Scholz, M., Soric, A., 676 Langergraber, G., 2015. Modelling constructed wetlands: Scopes and aims - a 677 comparative review. Ecol. Eng. 80, 205-213. 
678 Min, J.H., Paudel, R., Jawitz, J.W., 2011. Mechanistic biogeochemical model 679 applications for Everglades restoration: a review of case studies and suggestions for 680 future modeling needs. Critic. Rev. Environ. Sci. Technol. 41, 489-516.

681 Mulling, B.T.M., 2013. Particles matter: Transformation of suspended particles in 682 constructed wetlands.

683 Nagid, E.J., Canfield, D.E., Hoyer, M.V., 2001. Wind-induced increases in trophic state 684 characteristics of a large $(27 \mathrm{~km} 2)$, shallow (1.5 mean depth) Florida lake. 685 Hydrobiologia 455, 97-110.

686 Onandia, G., Gudimov, A., Miracle, M. R., Arhonditsis, G., 2015 Towards the 687 development of a biogeochemical model for addressing the eutrophication problems in 688 the shallow hypertrophic lagoon of Albufera de Valencia, Spain. Ecol. Inform. 26, 7068989.

690 Paudel, R., Jawitz, J.W., 2012. Does increased model complexity improve description 691 of phosphorus dynamics in a large treatment wetland? Ecol. Eng. 42, 283-294.

692 Reddy, K.R., DeLaune, R.D., 2008. Biogeochemistry of wetlands: science and 693 applications. CRC press.

694 Reichert, P. 1998. AQUASIM 2.0 - User Manual Computer Program for the 695 Identification and Simulation of Aquatic Systems. Swiss Federal Institute for 696 Environmental Science and Technology (EAWAG), CH-8600 Dubendorf, Switzerland. 697 Reynolds, C.S., 2006. The Ecology of Phytoplankton. Cambridge, UK. Cambridge 698 University Press.

699 Reichert, P., Borchardt, D., Henze, M., Rauch, W., Shanahan, P., Somlyódy, L., 700 Vanrolleghem, P., 2001. River Water Quality Model No.1. IWA Publishing. 
Rivers-Moore, N.A., de Moor, F.C., Birkholz, S.A., Palmer, R.A., 2006. Estimation of preferred water flow parameters for four species of Simulium (Diptera: Simuliidae) in small clear streams in South Africa. Afr. J. Aquat. Sci. 31, 261-269.

Samsó, R., García, J., 2013. BIO_PORE, a mathematical model to simulate biofilm growth and water quality improvement in porous media: application and calibration for constructed wetlands. Ecol. Eng. 54, 116-127.

Scheffer, M., Hosper, S. H., Meijer, M. L., Moss, B., Jeppesen, E., 1993. Alternative equilibria in shallow lakes. Trends Ecol. Evol. 8, 275-279.

Schmid, B.H., Stephan, S., Hengl, M.A., 2005. Sediment deposition in constructed wetland ponds with emergent vegetation: laboratory study and mathematical model. Wat. Sci. Tech. 51 (9), 307-314.

Schmidt, C., Musolff, A., Trauth, N., Vieweg, M., Fleckenstein, F.H., 2012. Transient analysis of fluctuations of electrical conductivity as tracer in the stream bed. Hydrol. Earth Syst. Sci. 16, 3689-3697.

Søndergaard, M., Kristensen, P., Jeppesen, E., 1992. Phosphorus release from 716 resuspended sediment in the shallow and windexposed Lake Arres $\varnothing$, Denmark. Hydrobiologia 228: 91-99.

Stone, K.C., Poach, M.E., Hunt, P.G., Reddy, G.B., 2004. Marsh-pond-marsh constructed wetland design analysis for swine lagoon waste water treatment. Ecol. Eng. $23,127-133$.

Tsanis, I. K., Prescott, K. L., Shen, H., 1998. Modelling of Phosphorus and Suspended Solids in Cootes Paradise Marsh. Ecol. Model. 114(1):1-17.

724 Wang, N., Mitsch, W.J., 2000. A detailed ecosystem model of phosphorus dynamics in created riparian wetlands. Ecol. Model. 126, 101-130. 
726 Wang, N., Mitsch, W. J., 2000. A detailed ecosystem model of phosphorus dynamics in

727 created riparian wetlands. Ecol. Model., 126(2-3), 101-130.

728 Wang, Y. C., Lin, Y. P., Huang, C. W., Chiang, L. C., Chu, H. J., Ou, W. S., 2012. A

729 system dynamic model and sensitivity analysis for simulating domestic pollution

730 removal in a freewater surface constructed wetland. Water Air Soil Pollut. 223(5),

$731 \quad 2719-2742$.

732 Weyhenmeyer, G.A., Hakanson, L., Meili, M., 1997. A validated model for daily 733 variations in the flux, origin and distribution of settling particles within lakes. Limnol.

734 Oceanogr. $42(7), 1517-1529$.

735 Wu, H., Huang, P., Wang, J., 2010. Treatment of eutrophic-lake water by free water 736 surface wetland. World Academy of Science. Eng. Technol., 67. 